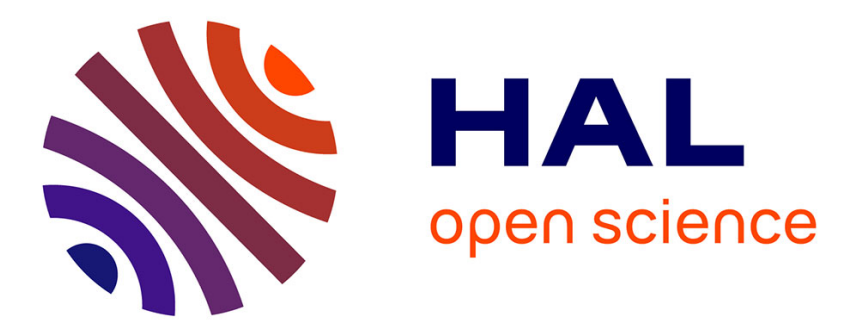

\title{
Experimental investigation of the phase equilibria and thermodynamic assessment in the U-Ga and U-Al-Ga systems
}

Charbel Moussa, Alexandre Berche, J. Barbosa, M. Pasturel, B. Stepnik, O. Tougait

\section{To cite this version:}

Charbel Moussa, Alexandre Berche, J. Barbosa, M. Pasturel, B. Stepnik, et al.. Experimental investigation of the phase equilibria and thermodynamic assessment in the U-Ga and U-Al-Ga systems. Journal of Nuclear Materials, 2018, 499, pp.361-371. 10.1016/j.jnucmat.2017.11.037 . hal-01671621

HAL Id: hal-01671621

https://hal-univ-rennes1.archives-ouvertes.fr/hal-01671621

Submitted on 2 Mar 2018

HAL is a multi-disciplinary open access archive for the deposit and dissemination of scientific research documents, whether they are published or not. The documents may come from teaching and research institutions in France or abroad, or from public or private research centers.
L'archive ouverte pluridisciplinaire HAL, est destinée au dépôt et à la diffusion de documents scientifiques de niveau recherche, publiés ou non, émanant des établissements d'enseignement et de recherche français ou étrangers, des laboratoires publics ou privés. 


\section{GRAPHICAL ABSTRACT :}

In present work, the phase equilibrium relations in the U-Al-Ga ternary system were investigated using key equilibrated alloys. Based on the experimental results from electronprobe microscopy analysis, x-ray diffraction techniques and DTA measurements, two isothermal sections were constructed at $900 \mathrm{~K}$ and $1150 \mathrm{~K}$. The phase diagram, which is characterized by the absence of ternary intermetallic phases, engages phase relations involving ternary extensions of the binary compounds with substitution mechanism between the $p$-elements only, and minute solubilities in metallic uranium. Thermodynamic assessment for the U-Al-Ga ternary system has been developed by means of the CALPHAD approach yielding a set of reliable thermodynamic parameters. Prior to the ternary investigation, uncertainties in the U-Ga binary system, motivated a reassessment of this binary phase diagram by combining an experimental approach on key compositions and a thermodynamic modelling.
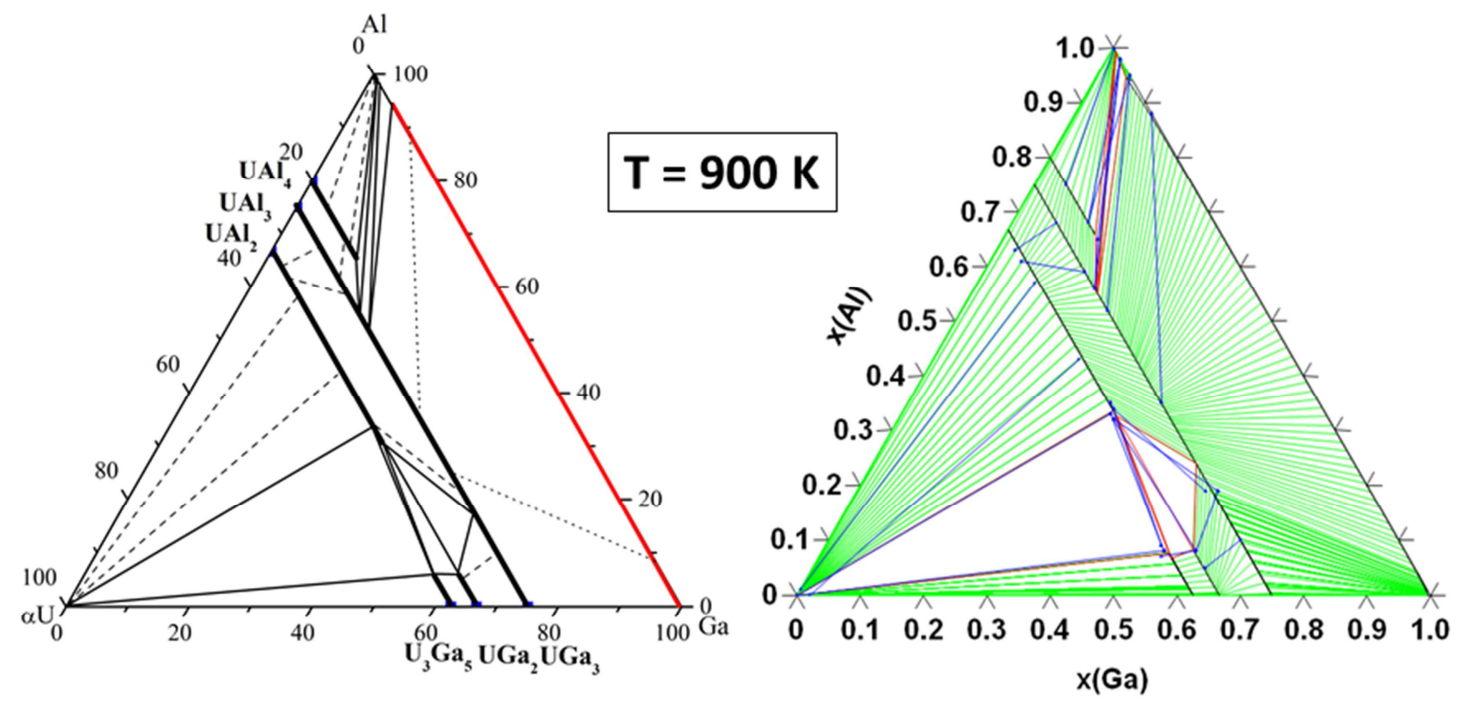


\title{
Experimental Investigation of the Phase Equilibria and Thermodynamic
} Assessment in the U-Ga and U-Al-Ga Systems.

Chantal. Moussa ${ }^{1}$, Alexandre Berche ${ }^{1}$, José Barbosa ${ }^{1}$, Mathieu Pasturel ${ }^{1}$, Bertrand Stepnik ${ }^{2}$ and Olivier Tougait ${ }^{1,3 *}$

${ }^{1}$ Institut des Sciences Chimiques de Rennes, Chimie du Solide et Matériaux, UMR CNRS 6226, Université Rennes 1, Campus de Beaulieu, 35042 Rennes Cedex, France

${ }^{2}$ AREVA/CERCA, 10 Rue Juliette Récamier, 69006 Lyon, France

${ }^{3}$ Univ. Lille, CNRS, Centrale Lille, ENSCL, Univ. Artois, UMR 8181-UCCS - Unité de Catalyse et Chimie du Solide, F-59000 Lille, France

* Corresponding author : O. Tougait (Olivier.tougait@univ-lille1.fr)

Present address : Université Lille 1, UCCS - Chimie du Solide, Cité Scientifique, Bâtiment C3, 59655 - Villeneuve d'Ascq Cedex, France

\begin{abstract}
The phase relations in the binary U-Ga and ternary U-Al-Ga systems were established as an isopleth section and two isothermal sections at $900 \mathrm{~K}$ and $1150 \mathrm{~K}$ for the whole concentration range, respectively. They were experimentally determined by means of powder and single crystal XRD, SEM-EDS analyses on both as-cast and heat-treated samples and DTA measurements. Both systems were thermodynamically assessed using the Calphad method based on all available data, i.e. phase relations and thermodynamic properties. The new description of the U-Ga phase diagram improves the composition and temperature description for most of invariant reactions. The U-Al-Ga system is characterized by large ternary extensions of the binary phases and the absence of ternary intermediate phase at both $900 \mathrm{~K}$ and $1150 \mathrm{~K}$. These experimental results are nicely reproduced by the Calphad assessment, allowing to extract the thermodynamic parameters further used to calculate the liquidus projection and the invariant reactions along with their temperature.
\end{abstract}

Keywords: U-based alloys, nuclear fuel, CALPHAD, phase diagram. 


\section{Introduction}

The specific physical chemistry properties of both trivalent $\mathrm{Al}$ and $\mathrm{Ga} p$-metals are regarded with great attention for nuclear applications: UAlx alloys are still used as fissile materials in research reactors [1], while Ga is used as $\delta$-stabilizer of the high temperature form of $\mathrm{Pu}$ [2]. In addition, $\mathrm{Ga}$ is regarded as one of the most efficient element for actinides and lanthanides separation by an electrorefining process in molten salt using a liquid metal electrode [3]. This pyrometallurgical process is considered as an alternative way for the reprocessing of spent fuels, especially the metallic ones and as a solid option for the recovery of pure Pu from the $\delta$-PuGa alloys. The high interest for the development of these innovative processes which requires a comprehensive analysis based on the validation of thermochemical parameters has motivated several research groups to publish very recently articles on the electrochemical properties [4], vaporization studies [5] and optimization of phase-relations [6] on systems involving $\mathrm{Al}, \mathrm{Ga}$ and actinide metals such as $\mathrm{U}$ and $\mathrm{Pu}$. In line with these studies, we have investigated the U-Al-Ga phase relations by an experimental way and a thermodynamic modeling using the CALPHAD method.

Prior to the investigation of the U-Al-Ga ternary system, a critical evaluation of the literature data on the U-Ga system revealed some doubts, which will be explicit in the following section, about composition, homogeneity domain, thermal stability and crystal structure for some binary compounds. To clear up these uncertainties, a reinvestigation of the phase relations in the U-Ga system by means of metallographic examinations on as-cast and annealed samples, DTA measurements up to $1600 \mathrm{~K}$ and single crystal diffraction was initiated to ascertain the occupancy rate of the crystallographic sites for $\mathrm{U}_{3} \mathrm{Ga}_{5}$. These supplementary results, along with the newly thermochemical data available $[4,5]$ were used for a thermodynamic reassessment of the U-Ga phase diagram. 
The present article summarizes both the experimental assessment and the thermodynamic optimization of the phase relations in the U-Ga and U-Al-Ga systems. It is organized as follow; after a short critical review on the literature data on the binary boundary systems and on the U-Al-Ga ternary one, the phase diagrams are presented into two subsections about the binary U-Ga system and the ternary U-Al-Ga one. Both of these subsections comprise experimental and modeling studies.

\section{Literature Data}

The review of the literature data about crystallographic as well as some thermodynamic properties of the unary and binary phases relevant to the present study is based on the critical assessment of the binary alloy phase diagrams by Massalski [7] as a starting point for the AlGa and U-Al systems. These assessments were completed and compared with some recent studies. For the U-Ga system, a rather compete analysis of the available literature data has been recently given in [5].

Regarding the Al-Ga system no revision has to be pointed out compared to the phase diagram presented in [7]. It is characterized by a rather limited solubility of Ga into solid Al to a maximum of about 9 at.\% and an eutectic reaction at $303 \mathrm{~K}$. The thermodynamic parameters used for the CALPHAD optimization of the ternary phase relations were taken from Watson [8].

The phase equilibria in the binary U-Al system are described in details in [9]. The phase diagram comprises three intermediate phases, $\mathrm{UAl}_{2}, \mathrm{UAl}_{3}$ and $\mathrm{UAl}_{4} . \mathrm{UAl}_{2}$ is characterized by a congruent melting point at $1893 \mathrm{~K}, \mathrm{UAl}_{3}$ and $\mathrm{UAl}_{4}$ form by peritectic reactions at $1623 \mathrm{~K}$ from $\mathrm{UAl}_{2}$ and at $1004 \mathrm{~K}$ from $\mathrm{UAl}_{3}$, respectively. The main conflict with more recent results concerns $\mathrm{UAl}_{4}$, which is a line compound whitout any polymorphic transformation related to an order ( $\alpha$ form) and a disorder ( $\beta$ form) of the possible vacancies [10]. The crystallographic 
properties of $\mathrm{UAl}_{2}, \mathrm{UAl}_{3}$ and $\mathrm{UAl}_{4}$ are undoubtedly described in the literature as crystallizing with cubic $\mathrm{MgCu}_{2}$ [11] cubic $\mathrm{AuCu}_{3}$ [12] and orthorhombic $\mathrm{UAl}_{4}$ [10] type of structures, respectively. Despite some inconsistencies with the recent experimental description of the UAl binary phase diagram, the thermodynamic parameters used in the present study were mainly based on the optimization of Wang et al. [13] which was slightly tuned to include the stoichiometric behavior of $\mathrm{UAl}_{4}[14]$.

Since the report of Buschow [15], all bibliographic reviews agree to describe the U-Ga system with three intermediate phases. The Ga-richest phase, $\mathrm{UGa}_{3}$ crystallizes with the $\mathrm{AuCu}_{3}$ cubic structure as mentioned $[15,16]$ and confirmed by neutron powder diffraction [17]. According to [15] it decomposes by peritectic reaction at $1523 \mathrm{~K}$ as $\mathrm{UGa}_{3} \rightarrow \mathrm{UGa}_{2}+\mathrm{L}$.

$\mathrm{UGa}_{2}$ has been identified by Makarov and Levdik [18] and reported by Rough and Bauer [19] . It crystallizes with the hexagonal $\mathrm{AlB}_{2}$ type of structure as suggested by Buschow [15] and confirmed by [17] at least down to $80 \mathrm{~K}$, a temperature at which a hexagonal to orthorhombic transition associated to magnetic ordering is supposed to occur [20]. More recently, it has been proposed [21] for $\mathrm{UGa}_{2}$ a new crystal structure based on the $\mathrm{Pu}_{3} \mathrm{Pd}_{5}$ prototype, which is stable at high temperature only. In addition, it is suggested that therefore, a continuous solid solution could exists between $\mathrm{UGa}_{2}$ and $\mathrm{U}_{3} \mathrm{Ga}_{5}$ compositions, but without further evidence about the phase relationships and transition temperatures [21]. This assumption is in disagreement with the DTA measurements [15], which does not show any transition below the congruent melting of $\mathrm{UGa}_{2}$ estimated at $1628 \mathrm{~K}$ and the crystallographic analysis of a single crystal directly grown from the melt which shows the $\mathrm{AlB}_{2}$ type of structure [22]. These conflicting observations for this composition range at high temperature required to be clarified.

The last phase is the richest one in uranium, which its chemical formula has been the subject to continuous debate. This compound was firstly reported with the UGa stoichiometry 
and crystallizing with an orthorhombic structure [18]. The composition was corrected to $\mathrm{U}_{2} \mathrm{Ga}_{3}$ by Buschow [15] who confirmed the orthorhombic symmetry of the phase. A more detailed investigation by Dayan [23] reports microprobe analysis (WDS) yielding an elemental composition of 63 at.\% Ga in accordance with a 3:5 stoichiometry and in good agreement between their XRD pattern with a simulated one considering the atomic positions of $\mathrm{Th}_{3} \mathrm{In}_{5}$ which crystallizes with the orthorhombic $\mathrm{Pu}_{3} \mathrm{Pd}_{5}$-type of structure. Their refined lattice parameters are comparable to those previously reported [19, 15]. According to [15] this U-richest phase has a pertictic decomposition at $1533 \mathrm{~K}$ yielding $\mathrm{UGa}_{2}$ and liquid.

The liquidus was drawn by joining the experimental points measured by DTA [15] revealing an eutectic composition at about 22 at.\% Ga with a melting point about $1303 \mathrm{~K}$. In this first complete version of the constitutional phase-diagram, the mutual solubility of the elements was not taken into account in concordance with an early report [24]. Significant solubility of $\mathrm{Ga}$ in $\gamma \mathrm{U}$ has been corrected to be 7.9 at.\% Ga at the eutectic plateau of 1292(10) $\mathrm{K}$ [25]. The solubility limits of $\mathrm{Ga}$ as function of the temperature in $\gamma \mathrm{U}$ and $\beta \mathrm{U}$ was evaluated by means of WDS measurements on annealed samples in the temperature range 953-1273 K [26] yielding 1.2 at.\% $\mathrm{Ga}$ in $\beta \mathrm{U}$ at $983 \mathrm{~K}$ and $8.2(1)$ at. $\% \mathrm{Ga}$ in $\gamma \mathrm{U}$ at $1273 \mathrm{~K}$. According to [23], the eutectoid composition associated to the transformation, $\beta \mathrm{U}(\mathrm{Ga}) \rightarrow \alpha \mathrm{U}+\mathrm{U}_{3} \mathrm{Ga}_{5}$ is estimated to be at 0.3 at.\% Ga, yielding a very limited solubility of Ga in $\alpha \mathrm{U}$. The solubility of $U$ in Ga was considered as very low in all studies following the early assessment [24] and recently confirmed by electrochemical measurements (fem) [4].

The thermodynamic properties of the U-Ga system have been determined by various research groups by means of quite different experimental techniques. The enthalpy of formation, was deduced from calorimetric measurements for $\mathrm{UGa}_{3}[27,28]$ and $\mathrm{UGa}_{2}$ [28] and from electromotive force measurements on galvanic cells for $\mathrm{UGa}_{3}$ [29] and for the liquid $+\mathrm{UGa}_{3}$ domain [29]. The Gibbs free energy of formation was further determined by Knudsen 
effusion mass spectrometry (KEMS) for UGa (identified as the U-richest phase), $\mathrm{UGa}_{2}$ and $\mathrm{UGa}_{3}$ [30], for $\mathrm{U}_{2} \mathrm{Ga}_{3}$ (identified as the U-richest phase) [25] and recently for $\mathrm{U}_{3} \mathrm{Ga}_{5}, \mathrm{UGa}_{2}$ and $\mathrm{UGa}_{3}[5]$.

The only available thermodynamic assessment of the U-Ga system is due to Wang et al. [31] which correctly reproduced the phase relationships of [32].

The critical review of the literature data on the U-Ga system emphasizes some uncertainties and weakness, which can be listed as follow :

- The experimental assessment of the phase relations and the temperature of the invariant reactions are exclusively based on the work of Buschow [15], which doesn't consider homogeneity domain for the intermediate phases and solubility of the elemental components.

- The stoichiometry and eventually the homogeneity domain of the U richest phase (i.e. $\mathrm{UGa}, \mathrm{U}_{2} \mathrm{Ga}_{3}$ or $\mathrm{U}_{3} \mathrm{Ga}_{5}$ ) is still unclear despite strong evidence for the 3:5 stoichiometry [23].

- The liquidus, composition stability and some possible phase transitions in the composition range between $\mathrm{UGa}_{2}$ and $\mathrm{U}_{3} \mathrm{Ga}_{5}$ are questionable. The liquidus measurements of Gardie et al., [25] and Buschow [15] between 50 and 78 at.\% $\mathrm{U}$ are divergent. Moreover, for this composition area the experimental data do not match well with the model of Wang et al. [31].

As a consequence, we chose to reinvestigate this region of the $\mathrm{U}-\mathrm{Ga}$ phase diagram. We also decided to check the stability domain and the possibility of polymorphic transformation for the $\mathrm{UGa}_{2}$ and $\mathrm{U}_{5} \mathrm{Ga}_{3}$ phases by using Differential Thermal Analysis (DTA) method and XRD technics. 
To the best of our knowledge, no ternary phase relation and no ternary intermetallic compound are reported for the U-Al-Ga ternary system and only some powder XRD analyses of the pseudo-binary compounds based on $\mathrm{UGa}_{2}$, and $\mathrm{UAl}_{2}$ are available. According to Kim et al., [33] the limit of Ga solubility in the cubic $\mathrm{UAl}_{2}$ is 25 at.\% $\mathrm{Ga}\left(\mathrm{UAl}_{1.25} \mathrm{Ga}_{0.75}\right)$ in as-cast samples. According to da Silva et al. [34] a single phase domain is retained for Ga substitution within the hexagonal $\mathrm{UGa}_{2-\mathrm{x}} \mathrm{Al}_{\mathrm{x}}$ up to $\mathrm{x}=0.1$ yielding stability up to 3.3 at. $\% \mathrm{Al}$ for the samples annealed at $973 \mathrm{~K}$.

Table 1 summarizes the main crystallographic data and some miscibilities for the unary and binary phases bounding the U-Al-Ga system.

\section{Please insert here Table 1}

\section{Experimental section.}

A total of about 70 samples were synthesized. The polycrystalline samples (each weighing $\sim 0.4 \mathrm{~g}$ ) have been prepared by melting the elemental components in an arc-furnace. The ingots were placed in alumina crucibles, then introduced and sealed in evacuated silica tubes under residual argon atmosphere. The reaction tubes were annealed at $900 \mathrm{~K}$ for nine weeks or at $1150 \mathrm{~K}$ for six weeks and then quenched to room temperature. Alternative heattreatments were carried out in a high-frequency furnace under low Ar-pressure, for some selected U-Ga binary ingots. They were placed into a copper cold-crucible for annealing in the temperature range 1473-1673 K, with dwell periods of about 6 hours. This annealing time was considered for a stabilized temperature with oscillations of about $\pm 20 \mathrm{~K}$.

Each sample was analyzed by powder x-ray diffraction (XRD) and its microstructure was studied on polished surfaces using scanning electron microscopy (SEM). 
XRD powder patterns were collected at room temperature using a Bruker AXS D8 Advance diffractometer $\left(\vartheta-2 \vartheta\right.$ Bragg-Brentano geometry, monochromatized $\mathrm{Cu} \mathrm{K} \alpha_{1}$ radiation, $\lambda=1.5406 \AA$ ), equipped with a LynxEye fast detector. The experimental diffraction patterns were compared to those calculated from known structure types using the FullProf software [35].

The microstructure of the samples was studied on polished surfaces using a Jeol JSM 7100F Scanning Electron Microscope (SEM) equipped with Silicon Drift Detector (SDD) X-Max 50 from Oxford Instrument employed for the elemental analysis of the various phases. Elemental compositions were obtained by averaging the values of at least three EDS analyzed zones, from different regions of the sample. Superimposed to the internal ZAF correction, external calibrations by using $\mathrm{U}, \mathrm{Ga}$ and $\mathrm{Al}$ metals and binary compounds with point composition or minute homogeneity range, such as $\mathrm{UAl}_{3}, \mathrm{UAl}_{2}$ and $\mathrm{UGa}_{3}$, were used to improve these semi-quantitative data. An estimated deviation from the mean value is about 1 at $\%$. The agreement between the targeted and the sample compositions was checked by measuring a large zone of the sample surface. In the following, the measured elemental composition is retained and denoted as nominal composition.

Qualitative Differential Thermal Analysis (DTA) was performed on a Setaram LabSys 1600 apparatus, calibrated using the phase transitions and melting temperatures of different pure metals, i.e. $\mathrm{Al}, \mathrm{Cu}, \mathrm{Fe}$. The measurement was performed up/down to/from $1773 \mathrm{~K}$ at a heating/cooling rate of $5 \mathrm{~K} \mathrm{~min}^{-1}$, under a $5 \mathrm{~N}$ purity argon flow.

Small single crystals suitable for crystal structure determination were picked up from the heat-treated samples. The diffraction intensities were collected at room temperature on a Nonius Kappa CCD four-circle diffractometer working with Mo $\operatorname{K\alpha }$ radiation $(\lambda=$ $0.71073 \AA$ ). The integration and reduction of redundant reflections of the different data sets as well as the cell refinements were performed using the SADABS software [36]. The structural 
model of $\mathrm{U}_{3} \mathrm{Ga}_{5}$ was determined by direct methods using SIR-97 [37] and all the structure refinements and Fourier syntheses were made with the help of SHELXL-13 [38].

\section{CALPHAD method.}

The thermodynamic modeling using the calculation of phase diagrams, including isopleth and isothermal sections, by CALPHAD method [39] was carried out using the PARROT module implemented in the Thermo-Calc software [40]. The Gibbs energy functions of the pure elements, chosen in their reference state at $T=298.15 \mathrm{~K}$ and $p=0.1 \mathrm{MPa}$ or metastable state, were taken from the SGTE database presented by Dinsdale [41]. The excess term of all the phases were modeled as random solutions using the Redlich-Kister polynomial functions. The description of the Gibbs energy $\left({ }^{0} \mathrm{G}_{\mathrm{i}}\right)$ is given for each phase by:

$$
\begin{aligned}
{ }^{0} G_{i}-\sum_{i=A, B, C} x_{i}{ }^{0} H_{i}^{S E R}(298.15 K)={ }^{r e f} G+{ }^{i d} G+{ }^{X S} G & \text { (I) } \\
G^{\varphi}-\sum_{i=U, A l, G a} x_{i}^{\varphi} \cdot H_{i}^{S E R}(298.15 K) & ={ }^{r e f} G^{\varphi}+{ }^{i d} G^{\varphi}+{ }^{e x} G^{\varphi}
\end{aligned}
$$

where $x_{i}$ is the molar fraction of the $i$ element, $H_{i}^{S E R}$ represents the enthalpy of the pure element $i$ and the reference term is:

$$
{ }^{r e f} G=\sum_{i=A, B, C} x_{i}\left({ }^{0} G_{i}(T)-{ }^{0} H_{i}^{S E R}(298.15 K)\right.
$$

where ${ }^{0} G_{\mathrm{i}}$ is the standard Gibbs energy of element $\mathrm{i},{ }^{0} H_{\mathrm{i}}$ is the standard enthalpy of the pure element $\mathrm{i}$ and the ideal term is:

$$
{ }^{i d} G=R T \sum_{i=A, B, C} x_{i} \ln \left(x_{i}\right)
$$

$\mathrm{R}$ is the universal gas constant and the excess term is: 


$$
{ }^{X S} G=x_{A} x_{B} x_{c} \sum_{n} x_{i}{ }^{n} L_{A, B, C}\left(x_{A}-x_{B}-x_{c}\right)^{n}
$$

with the interaction parameter is defined as ${ }^{n} L_{A, B, C}=a+b . T$

\section{Results}

\subsection{The uranium-gallium system.}

The objectives of this work on the U-Ga system is to reassess the phase relations by the CALPHAD method using the new thermodynamic data available $[4,5]$ and our experimental results about some thermochemical parameters. A close attention has been paid on the stoichiometry, the crystal structure, the homogeneity range and the thermal stability of the three intermediate phases.

\subsection{1. experimental investigation}

Samples with nominal composition in the $25-70$ at $\% \mathrm{U}$ range were arc-melted. The solidified ingots were used for examination in the as-cast or heat-treated states. The thermal treatments were performed either at $1400 \mathrm{~K}$ for 6 hours or at $1150 \mathrm{~K}$ for 3 weeks. All the samples were characterized by powder XRD, SEM-EDS and DTA measurements, in order to check the phase relations between the three intermediate phases and to determine the temperature of the invariant reactions. Table 2 presents the SEM-EDS and powder XRD of the samples for the different metallurgical states, as-cast and annealed ones.

\section{Please insert here Table 2}

For all the samples, the EDS analyses show that the three intermediate phases have elemental composition in agreement with the calculated atomic ratios for $\mathrm{U}_{3} \mathrm{Ga}_{5}, \mathrm{UGa}_{2}$ and $\mathrm{UGa}_{3}$, at any temperature, suggesting line compounds in the whole investigated temperature domain, i.e. from their temperature of formation down to $1150 \mathrm{~K}$ at least. In line with such a 
statement, the refined lattice parameters for the three intermediate phases for all samples and for any temperatures remain in narrow ranges, indicating the absence of homogeneity domain. The Ga solubility in $\mathrm{U}$ which amounts to $8(1)$ at.\% for the eutectic temperature is in agreement with the reported value [26]. It was estimated from as-cast samples by considering an EDS analyzed area of $2 \times 2 \mu \mathrm{m}$ within homogeneous eutectoid zones. The eutectoid transformation is readily confirmed on XRD patterns showing $\alpha \mathrm{U}$ phase, which should be better described as $\alpha^{\prime}$ form due to structural distortions [42, 43]. Despite some obvious mismatches with the orthorhombic symmetry, the refinement of the lattice parameters considering this monoclinic modification did not converge to clear values to be presented in table 2. The eutectic composition at the U-rich side is estimated at 76 at.\% U, slightly poorer than the reported 78 at.\% $\mathrm{U}$ value [15]. The as-cast samples in the composition range $\mathrm{U}_{3} \mathrm{Ga}_{5}-$ $\mathrm{UGa}_{2}$ were found systematically biphasic, composed of $\mathrm{U}_{3} \mathrm{Ga}_{5}$ with the $\mathrm{Pu}_{3} \mathrm{Pd}_{5}$-type and of $\mathrm{UGa}_{2}$ with the $\mathrm{AlB}_{2}$-type, ruling out the assumption of a solid solution at high temperature [21].

The temperature of the invariant reactions, which were measured by DTA using samples annealed at $1100 \mathrm{~K}$ are listed in Table 3 . For the composition range 52 to 18 at.\% U, the reaction temperature derived from our DTA measurements were found slightly higher than the previous values [15] as depicted in Fig.1. The largest difference is an increase of about $25 \mathrm{~K}$ of the peritectic temperature of formation of $\mathrm{UGa}_{3}$ and of the liquidus of this elemental composition. Most of the other temperatures were in reasonable agreement with the reported values $[15,25]$.

\section{Please insert here Table 3}

The crystal-structure of $\mathrm{U}_{3} \mathrm{Ga}_{5}$ was refined from single-crystal diffraction, using a fragment of a crushed ingot with an initial composition of 38U-62Ga (nominal composition U39Ga61) heat-treated at $1373 \mathrm{~K}$ for 6 hours. Examination of the single crystal data collection revealed 
that the extinction conditions were consistent with the orthorhombic space group $\mathrm{Cmcm}$ (no. 63). The refined atomic parameters, initially determined by direct method, readily converged to a structural model of the $\mathrm{Pu}_{3} \mathrm{Pd}_{5}$-type, without any deviation from a full occupancy of all the crystallographic sites. The final Fourrier synthesis was found featureless. All the interatomic distances match the sum of the metallic radius of $\mathrm{U}(1.53 \AA)$ and $\mathrm{Ga}(1.40 \AA)$ [44] with coordination polyhedron typically encountered for the U-based intermetallics. The relevant data concerning the single crystal x-ray diffraction data collection are gathered in Table 4. The atomic positional and thermal displacement parameters are listed in Table 5.

\section{Please insert here Table 4 and Table 5}

\subsubsection{Thermodynamical assessment}

Combining these new data of crystal-chemistry with the recent thermodynamic measurements reported $[4,5]$, the U-Ga system was assessed using the Calphad method. The calculated phase diagram in the U-Ga system, with all experimental data used in the present optimization is depicted in Fig. 1, along with a comparison with liquidus and solidus data. The least-square optimization was carried out by giving a prominent weight to the newly experimental results $[4,5$, this work] for the Ga-rich part (above 60 at. $\% \mathrm{Ga}$ ) and to the vapor pressure [24] and solubility [25] measurements for the U-rich side (above 80 at.\% U). The liquid, $\gamma \mathrm{U}$ and $\beta \mathrm{U}$ were modeled as random solutions without short-range order model. The maximum solubility was found to be 8.5 at.\% Ga and 1.1 at.\% Ga for $\gamma \mathrm{U}$ and $\beta \mathrm{U}$ at 1293 and $1014 \mathrm{~K}$, respectively. These values are in good agreement with the experimental values measured. In agreement with the experimental data no solubility was accounted for $\alpha \mathrm{U}$ and Ga. The three intermediate phases $\mathrm{U}_{3} \mathrm{Ga}_{5}, \mathrm{UGa}_{2}$ and $\mathrm{UGa}_{3}$ were described as stoichiometric compounds. The presently optimized set of parameters is given in Table 6 . 


\section{ACCEPTED MANUSCRIPT}

\section{Please insert here Table 6}

\section{Please insert here Figure 1}

The thermodynamic parameters optimized in the present work were used to calculate various thermodynamic parameters such as enthalpy of formation. Fig.2 compares these latter values with the available ones of the intermetallic compounds, experimentally measured [5, 25, 27-29] or assessed using the Calphad method in a previous study [31]. Two sets of experimental values separated by about $10 \mathrm{~kJ} \mathrm{~mol}^{-1}$ can be distinguished. The calculated values by Wang et al., [31] lie in the middle of this gap whereas our modeling results lead to more negative ones in agreement with most recent experimental data of calorimetric study [28].

\section{Please insert here Figure 2}

5.2 The uranium-aluminium-gallium system

\subsection{1. experimental investigation}

The experimental isothermal sections at $900 \mathrm{~K}$ and $1150 \mathrm{~K}$ of this ternary system determined in this work are shown in Fig. 3 and Fig. 4, respectively. The subsolidus phaserelations were derived by comparison of the XRD patterns and SEM-EDS-analyses of the annealed samples. The crystalline form identified by XRD and the measured composition in the various three-phase fields determined within the isothermal section are listed in Table 7 and Table 8 for 900 and $1150 \mathrm{~K}$ respectively. The thicker solid lines represent the homogeneity domains of the pseudo-binary or ternary phases, the thinner ones for the limits of the three-phase fields and the dashed lines represent the experimental tie-lines.

\subsubsection{Isothermal section at low temperature $(900 \mathrm{~K})$}


The elemental composition and the structural form of the six binary phases, stable at $900 \mathrm{~K}$, have been confirmed. Substitution mechanism engages the $p$-block elements only. Beside the complete miscibility between $\mathrm{UAl}_{3}$ and $\mathrm{UGa}_{3}$, the four other binaries show extended ternary extensions. The Ga solubility amounts to $36(1)$ at.\% in $\mathrm{UAl}_{2}$ and $15(1)$ at.\% in $\mathrm{UAl}_{4}$ whereas the $\mathrm{Al}$ solubility amounts to $6(1)$ at.\% in both $\mathrm{UGa}_{2}$ and $\mathrm{U}_{3} \mathrm{Ga}_{5}$. All these pseudo-binary compounds, including the $\mathrm{UAl}_{3}-\mathrm{UGa}_{3}$ solid solution retain their crystallographic form. No evidence of superstructure formation resulting from an $\mathrm{Al}$ to $\mathrm{Ga}$ ordering could be detected on the powder XRD patterns.

\section{Please insert here Table 7}

Please insert here Figure 3

\subsubsection{Isothermal section at high temperature $(1150 \mathrm{~K})$}

The isothermal section at $1150 \mathrm{~K}$ was studied in the composition area between 100 to 25 at $\% \mathrm{U}$ due to the large extension of the $(\mathrm{Al}, \mathrm{Ga})$ liquid phase at this temperature. The crystalline form and the measured compositions defining the limits of the three-phase fields as well as some tie-lines within two-phase field domains are presented in Table 8. No miscibility of U in Ga and Al, above the absolute error of EDS measurements (1 at \%) could be detected. The solubility of $\mathrm{Al}$ and $\mathrm{Ga}$ in $\gamma \mathrm{U}$, was found to be about 2(1) and 7(1) at \%, respectively. These values are slightly lower than those estimated at $1150 \mathrm{~K}$ from the corresponding binary phase diagrams. These values were deduced from EDS analyses performed in surface areas of about $2 \mathrm{x} 2 \mu \mathrm{m}^{2}$ and were considered as representative of the high temperature conditions, despite that the $b c c$-form of $\mathrm{U}(\gamma \mathrm{U})$ was not retained by water quenching. 
Again, a continuous solid solution between $\mathrm{UGa}_{3}$ and $\mathrm{UAl}_{3}$ is observed. The Ga solubility amounts to $37(1)$ at.\% in $\mathrm{UAl}_{2}$ whereas the $\mathrm{Al}$ solubility amounts to $6(1)$ at.\% in $\mathrm{UGa}_{2}$ and 7(1) at.\% in $\mathrm{U}_{3} \mathrm{Ga}_{5}$.

The study of both isothermal sections reveals that with the exception of $U$ itself the miscibility concerns the $p$-elements only, and no deviation from the expected U-content was measured in any of the intermetallic phases.

\subsubsection{Thermodynamic assessment}

The assessed parameters gathered in Table 9 accurately reproduce the experimental composition limits and the equilibrium relations of the U-Al-Ga system at $900 \mathrm{~K}$ (Fig. 6a) and $1150 \mathrm{~K}$ (Fig. 6b). For both temperatures, the main differences with the experimental measurements consist of some mismatches between the experimental and calculated tie-lines involving the $\mathrm{UX}_{3}$ phase. At $900 \mathrm{~K}$, they are observed for the three following the two-phase field domains: (i) between $\mathrm{UAl}_{2-\mathrm{x}} \mathrm{Ga}_{\mathrm{x}}$ and $\mathrm{UAl}_{3-\mathrm{x}} \mathrm{Ga}_{\mathrm{x}}$, (ii) $\mathrm{UGa}_{2-\mathrm{x}} \mathrm{Al}_{\mathrm{x}}$ and $\mathrm{UGa}_{3-\mathrm{x}} \mathrm{Al}_{\mathrm{x}}$, and (iii) liquid $(\mathrm{Al}, \mathrm{Ga})$ and $\mathrm{UX}_{3}$ with $\mathrm{X}=\mathrm{Al}$, Ga. At $1150 \mathrm{~K}$, again the only tie-lie experimentally determined within the $\mathrm{UAl}_{2-\mathrm{x}} \mathrm{Ga}_{\mathrm{x}}$ and $\mathrm{UAl}_{3-\mathrm{x}} \mathrm{Ga}_{\mathrm{x}}$ presents a disorientation.

\section{Please insert here Table 9 \\ Please insert here Figure 5}

The calculated liquidus projection is displayed in Fig. 7 along with the primary solidification phases. The calculated invariant reactions involving the liquid with their temperatures are listed in Table 10. Even if these results were obtained without any data about the liquidus curve, the predicted phase formations from the liquid compare well with the experimental phase identification carried out on as-cast samples, showing the primary solidification of all the binary and unary phases involved in the ternary system. 
Please insert here Figure 6

Please insert here Table 10

\section{Conclusion}

A bibliographic survey of the U-Ga system revealed some uncertainties and lack of experimental data, especially in the composition range 20-80 at.\% U, yielding discordant descriptions between the experimental and calculated phase diagrams. Detailed analyses of selected samples within this composition range were carried out by means of SEM-EDS, DTA measurement and XRD on powder and single crystal. The combination of these experimental results along with some recent experimental thermodynamic data $[4,5]$ with a Calphad optimization yield some improvements of the description of the U-Ga phase diagram:

- $\quad$ a small adjustment of the eutectic composition at the U-rich side (76 at.\% U)

- the confirmation of the stoichiometry of the U-richest phase as $\mathrm{U}_{3} \mathrm{Ga}_{5}$ crystallizing with the $\mathrm{Pu}_{3} \mathrm{Pd}_{5}$-type.

- a slight increase of the temperature of the peritectic decomposition of $\mathrm{UGa}_{3}$ along with the liquidus temperature for this composition.

- a weak increase of the melting temperature of $\mathrm{UGa}_{2}$ along with the liquidus temperature in the composition range 10 to 50 at. $\% \mathrm{U}$.

Two isothermal sections of the U-Al-Ga ternary system were established for $900 \mathrm{~K}$ and $1150 \mathrm{~K}$. They have been constructed using typical experimental techniques by combining the results of SEM-EDS and XRD analyses of annealed samples. Both of these isothermal sections are characterized by the absence of formation of ternary phase. The phase relations involve mostly the ternary extensions of the binary phases which were found to engage 
substitution mechanisms with the p-block elements only. It results in large homogeneity domains for these pseudo-binary phases, including $\mathrm{UAl}_{4}$ at $\mathrm{T}=900 \mathrm{~K}$ and to a complete solid solution between $\mathrm{UAl}_{3}$ and $\mathrm{UGa}_{3}$ adopting the $\mathrm{Cu}_{3} \mathrm{Au}$-type for both temperatures.

The modeling of these isothermal sections was carried out by the Calphad method, allowing the reproduction with fairly good agreement of the experimental composition limits and the equilibrium relations of the U-Al-Ga system at both 900 and $1150 \mathrm{~K}$. The main discrepancies with experimental measurements lie in a disorientation of some lie-lines implying the $\mathrm{UX}_{3}$ solid solution. The origin of these slight discrepancies remain unclear, but may be ascribed to insufficient effect of homogenization heat-treatments to fully remove the as-solidified microstructure. The assessed ternary thermodynamic parameters were used to calculate the liquidus projection and the invariant reactions along with their corresponding temperatures, which are given to complete the description of the U-Al-Ga phase diagram. The analyses of a few as-cast samples and modeling of the phase relations for several temperatures support the impressive general agreement between all data.

\section{Acknowledgements.}

The authors are also thankful to AREVA NP and CNRS for sponsoring this $\mathrm{PhD}$ study (LS80959). L. Joanny and/or F. Gouttefangeas are acknowledged for SEM images and EDS analyses performed at CMEBA (ScanMAT, University of Rennes 1) which received a financial support from the Région Bretagne and European Union (CPER-FEDER 2007-2014). We also thank S. Fryars for some syntheses and for her precious role in the management of the U samples.

\section{References}

[1] Y. S. Kim, Uranium intermetallic fuels (U-Al, U-Si, U-Mo), in: R.J.M. Konings (Ed.), Comprehensive Nuclear Materials, vol. 3, Elsevier, Amsterdam, 2012, 391-422. 
[2] D.E. Peterson, M.E. Kassner, The Ga-Pu (Gallium-Plutonium) system, Bull Alloy. Phase Diagrams, 9 (1988) 261-267.

[3] D. Lambertin, S. Ched'homme, G. Bourges, S. Sanchez, G.S. Picard, Activity coefficients of plutonium and cerium in liquid gallium at $1073 \mathrm{~K}$ : Application to a molten salt/solvent metal separation concept, J. Nucl Mater., 341 (2005) 131-140.

[4] V.A. Volkovich, D.S. Maltsev, L.F. Yamshchikov, A.G. Osipenko, Thermodynamic properties of uranium in liquid gallium, indium and their alloys, J. Nucl Mater., 464 (2015) 263-269.

[5] P. Manikandan, V.V. Trinadh, Suranjan Bera, T. S. Lakshmi Narasimhan, M. Joseph, High temperature mass spectrometric studies on U-Ga system: Thermodynamic properties over (U3Ga5 + UGa2) and (UGa2 + UGa3) phase regions, J. Nucl. Mater., 475 (2016) 87-93.

[6] A. Perron, P.E.A. Turchi, A. Landa, B. Oudot, B. Ravat, F. Delaunay, Thermodynamic assessments and inter-relationships between systems involving $\mathrm{Al}, \mathrm{Am}, \mathrm{Ga}, \mathrm{Pu}$, and $\mathrm{U}, J$. Nucl. Mater., 482, (2016) 187-200.

[7] T.B. Massalski, H. Okamoto, P.R. Subramanian, L. Kacprzak (Eds.), Binary Alloy Phase Diagrams, vols. 1-3, second ed., ASM International, 1990.

[8] A. Watson, Re-assessment of phase diagram and thermodynamic properties of the Al-Ga system, Calphad, 16 (1992) 207-217.

[9] M.E. Kassner, P.H. Adler, M.G. Adamson, D.E. Peterson, Evaluation and thermodynamic analysis of phase equilibria in the U-Al system, J. Nucl. Mater., 167 (1989) 160-168.

[10] O. Tougait, H. Noël, Stoichiometry of $\mathrm{UAl}_{4}$, Intermetallics, 12 (2004) 219-223.

[11] S. Steeb, G. Petzow, Strukturelle Veränderungen der Laves-Phasen $\mathrm{ZrAl}_{2}$ und $\mathrm{UAl}_{2}$ durch Uran- bzw. Zirkonzusätze, Naturwissenschaften, 48 (1961) 450.

[12] R.E. Rundle, A.S. Wilson, The Structures of some Metal Compounds of Uranium, Acta Crystallogr., 2 (1949) 148-150.

[13] J. Wang, X.J. Liu, C.P. Wang, Thermodynamic modeling of the Al-U and Co-U systems, J. Nucl. Mater., 374 (2008) 79-86.

[14] X. Zhang, Y.F. Cui, G.L. Xu, W.J. Zhu, H.S. Liu, B.Y. Yin, Z.P. Jin, Thermodynamic assessment of the U-Mo-Al system, J. Nucl. Mater., 420 (2010) 15-24.

[15] K.H.J. Buschow, Phase relationships and magnetic properties of uranium-gallium compounds, J. Less-Common Met., 31 (1973) 165-168.

[16] ] B.R.T. Frost, J.T. Maskrey, The system uranium-lead, J. Inst. Met. 82 (1953/54) 171180. 
[17] A.C. Lawson, A. Williams, J.L. Smith, P.A. Seeger, J.A. Goldstone, J.A. O'Rourke, Z. Fisk, Magnetic neutron diffraction study of $\mathrm{UGa}_{3}$ and $\mathrm{UGa}_{2}$, J. Magn. Magn Mater., 50 (1985) 83-87.

[18] E.S. Makarov, V.A. Levdik, Crystal structure of $\mathrm{UGa}$ and $\mathrm{UGa}_{2}$, Soviet physics Crystallography, 1 (1956) 506-510.

[19] F.A Rough, A.A. Bauer, Constitution of uranium and thorium alloys, BMI-1300, 1958

[20] A. V. Andreev, K. P. Belov, A. V. Deryagin, Z. A. Kazeǐ, R. Z. Levitin, A. Meňovský, Yu. F. Popov, V. I. Silant'ev, Crystal structure, and magnetic and magnetoelastic properties of $\mathrm{UGa}_{2}$, J. Exp. Theor. Phys., 48, (1978) 1187.

[21] A.P. Gonçalves, L. Havela, Crystal structure of a new $\mathrm{UGa}_{2}$ phase, J. Alloys Compd., 394 (2005) L1-L4.

[22] L. Havela, A.V. Kolomiets, V. Sechovsky, P. Javorsky, T.D. Cuong, J. Kamarad, N. Sato, Magnetic and transport properties of $\mathrm{UGa}_{2}$, Acta Physica Slovaca, 48 (1998) 803-806.

[23] D. Dayan, G. Kimmel, M.P. Dariel, Shear-like transformation in $\beta$-stabilized U-1.5 at.\% Ga alloy; structure of the intermetallic compound $\mathrm{U}_{3} \mathrm{Ga}_{5}$, J. Nucl. Mater., 135 (1985) 40-45.

[24] F.A. Rough, A.A. Bauer, Constitution of uranium and thorium alloys, US Atom. Energy Commun. BMI-1300 (1958).

[25] P. Gardie, G. Brodier, J.J. Poupeau, J. Le Ny, Thermodynamic activity measurements of U-Fe and U-Ga alloys by mass spectrometry, J. Nucl. Mater., 189 (1992) 85-96.

[26] S. Salhov, G. Kimmel, M.P. Dariel, Contribution to the uranium-gallium phase diagram, J. Alloys Compd. 444-445 (2007) 257-260.

[27] A. Palenzona, S. Cirafici, Thermodynamic properties of $\mathrm{Y}$, Th and $\mathrm{U}, \mathrm{MX}_{3}$ compounds with IIIA and IVA elements, Thermochim. Acta, 13 (1975) 357-360.

[28] B. Prabhakara Reddy, R. Babu, K. Nagarajan, P.R. Vasudeva Rao, Enthalpies of formation of $\mathrm{UGa}_{2}$ and $\mathrm{UGa}_{3}$ by calorimetry, J. Alloys Compd., 271-273 (1998) 395-399

[29] V.A. Lebedev, V.N. Seregin, A.M. Poyarkov, I.F. Nichkov, S.P. Raspopin, Thermodynamic properties of liquid U-Ga alloys, Russ. J. Phys. Chem., 47 (1973) 402-403.

[30] C.B. Alcock, J.B. Cornish, P. Grieveson, Knudsen effusion studies of compounds of uranium and thorium with elements of groups IIIb and IVb, Proc. Symp. Thermodyn. Nucl. Mater., IAEA, Vienna, 211 (1966) 211-230.

[31] J. Wang, X.J. Liu, C.P. Wang, J. Nucl. Mater., 380 (2008) 105-110.

[32] H. Okamoto, Desk Handbook-Phase Diagrams for Binary Alloys, ASM International, Materials Park, $(\mathrm{OH}) 2000$.

[33] J.S. Kim, W.W. Kim, G.R. Stewart, Hybridization and its influence on the electronic properties of $\mathrm{UAl}_{2}$, J. Alloys Compd., 202 (1993) 265-267. 
[34] L.M. da Silva, F.G. Gandra,, D.P. Rojas, L.P. Cardoso, A.N. Medina, Magnetic properties of $\mathrm{U}\left(\mathrm{Ga}_{1-\mathrm{x}} \mathrm{M}_{\mathrm{x}}\right)_{2}$ with $\mathrm{M}=\mathrm{Cu}, \mathrm{Al}$ and $\mathrm{Ge}$, Physica B, 312-313 (2002) 906-908.

[35] J. Rodriguez-Carvajal, Recent advances in magnetic structure determination by neutron powder diffraction, Physica B, 192 (1993) 55-69.

[36] Brüker-AXS, In: Collect, Denzo, Scalepack, Sortav. Kappa CCD Program Package, Delft, The Netherlands, 1998.

[37] A. Altomare, M. C. Burla, M. Camalli, G. L. Cascarano, C. Giacovazzo, A. Guagliardi, A. G. G. Moliterni, G. Polidori, R. Spagna, SIR97: a new tool for crystal structure determination and refinement, J. Appl. Crystallogr.,32 (1999) 115.

[38] G.M. Sheldrick, Crystal structure refinement with SHELXL, Acta Crystallogr. Sect C, 71 (2015) 3-8.

[39] L. Kaufman, H. Bernstein, Computer calculation of phase diagram, Refractory Materials. A Series of Monographs. Academic Press Inc; New York, 4 (1970) 344.

[40] J.O. Andersson, T. Helander, L. Höglund, P.F. Shi, B. Sundman, Thermo-Calc and DICTRA, Computational tools for materials science, Calphad, 26 (2002) 273-312.

[41] A. T. Dinsdale, SGTE Data for pure elements, Calphad, 15 (1991) 317-425.

[42] J. Lehmann, Phases monocliniques dans les alliages uranium-molybdène, J. Nucl. Mater., 4 (1961) 218-225.

[43] K. Tangri, G.I. Williams, Metastable phases in the uranium-molybdenum system and their origin, J. Nucl. Mater., 4 (1961) 226-233.

[44] E. Teatum, K. Gschneidner, J. Waber, in Compilation of calculated data useful in predicting metallurgical behavior of the elements in binary alloy systems, LA-2345, Los Alamos Scientific Laboratory (1960). 


\section{FIGURE CAPTIONS :}

Figure 1 : Calculated U-Ga phase diagrams (this work and [31]) compared to experimental liquidus and solidus temperatures as well as solubility limits of $\mathrm{Ga}$ in $\mathrm{U}$ allotropic forms [4, $15,25,26]$.

Figure 2 : assessed enthalpies of formation at 298K compared to experimental and assessed data. KEMS is Knudsen Effusion Mass Spectrometry and e;m.f. are electromotive forces measurements.

Figure 3 : Experimental isothermal section at $900 \mathrm{~K}$ of the U-Al-Ga ternary system. The black solid lines delimit the three-phase fields. The dashed lines represent the experimental tie-lines. The thick black lines correspond to the homogeneity domains of the solid phases. The red line along the Al-Ga axis stands for the liquid zone and the thin dotted lines correspond to the equilibrium with the liquid phase.

Figure 4 : Experimental isothermal section at $1150 \mathrm{~K}$ of the U-Al-Ga ternary system. The black solid lines delimit the three-phase fields. The dash lines represent the experimental tielines. The thick black lines and black area correspond to the homogeneity domains of the unary and binary phases. The red line along the Al-Ga axis stands for the liquid zone.

Figure 5 : Calculated isothermal sections of the U-Al-Ga system at $900 \mathrm{~K}$ (left) and $1150 \mathrm{~K}$ (right) along with the superimposition of the experimental tie-lines depicted as blue lines. Solid solutions are depicted as black lines. For the assessed isothermal section, the thin green lines stand for the lie-lines and red lines correspond to the limits of the three-phase fields. .

Figure 6. Calculated liquidus surface of U-Al-Ga using the present set of thermodynamical parameters. 


\section{TABLE CAPTIONS :}

Table 1 : Reported crystallographic and stability data of the unary and binary phases encountered in the U-Al-Ga ternary system.

Table 2 : SEM-EDS and powder XRD of the samples for the three different metallurgical states, denoted at as-cast, $1150 \mathrm{~K}$ and $\mathrm{HF}$ standing for arc-melted, annealed at $1150 \mathrm{~K}$ for three weeks in silica tube and annealed in a cold crucible coupled to a HF generator for 6 hours at about $1500 \mathrm{~K}$, respectively. The elemental compositions are given with an absolute error of \pm 0.5 at. $\%$.

Table 3 : Invariant reactions in the U-Ga system. The temperature were measured by DTA method and the transformations were confirmed by SEM-EDS and powder XRD analyses. The absolute error on the temperature is estimated to $\pm 3 \mathrm{~K}$.

Table 4: Single crystal data and structure refinement parameters of $\mathrm{U}_{3} \mathrm{Ga}_{5}$.

Table 5: Positional and equivalent isotropic thermal displacement parameters $\left(\AA^{2}\right)$ for $\mathrm{U}_{3} \mathrm{Ga}_{5}$

Table 6 : Gibbs energy parameters for the U-Ga system. The optimized parameters are in bold. Other parameters are taken from the SGTE database [39].

Table 7 : Phase compositions (in at.\%) in the three-phase fields as well as some tie-lines used to ascertain various solubilities in the isothermal section at $900 \mathrm{~K}$ of the U-Al-Ga ternary system. All EDS figures are given with an error of \pm 1 at. $\%$. $\mathrm{UX}_{3}$ stands for the $\mathrm{Au}_{3} \mathrm{Cu}$-type which is adopted by both $\mathrm{UAl}_{3}$ and $\mathrm{UGa}_{3}$.

Table 8 : Phase compositions (in at \%) in the three-phase fields as well as some tie-lines used to ascertain various solubilities in the isothermal section at $1150 \mathrm{~K}$ of the U-Al-Ga ternary system. All EDS figures are given with an error of \pm 1 at. $\%$. $\mathrm{UX}_{3}$ stands for the $\mathrm{Au}_{3} \mathrm{Cu}$-type which is adopted by both $\mathrm{UAl}_{3}$ and $\mathrm{UGa}_{3}$. 
Table 9 : Gibbs energy parameters in the u-Al-Ga system. The parameters for the Al-Ga system were taken from [8], those for the U-Al system from [13] and those for the U-Ga system from Table 6 . The assessed parameters are outlined in bold font. $\mathrm{UX}_{3}$ stands for both $\mathrm{UAl}_{3}$ and $\mathrm{UGa}_{3}$.

Table 10 : Calculated invariant reactions in the U-Al-Ga system. 
TABLES :

Table 1.

\begin{tabular}{|c|c|c|c|c|c|c|c|c|c|}
\hline Phase & $\begin{array}{c}\text { Structure- } \\
\text { type }\end{array}$ & $\begin{array}{c}\text { Space } \\
\text { group }\end{array}$ & \multicolumn{2}{|c|}{ Lattice parameters $(\AA)$} & $\begin{array}{c}\text { Stability } \\
\text { range (K) }\end{array}$ & $\begin{array}{c}\text { Composition } \\
\text { range (900K) }\end{array}$ & $\begin{array}{c}\text { Composition } \\
\text { range } \\
(1150 \mathrm{~K})\end{array}$ & ref \\
\hline$\alpha \mathrm{U}$ & $\alpha \mathrm{U}$ & $\mathrm{Cmcm}$ & 2.854 & 5.867 & 4.954 & $<941$ & $<0.1$ at \% Al & & 9 \\
\hline$\beta \mathrm{U}$ & $\beta \mathrm{U}$ & $P 4_{2} n m$ & 10.590 & 10.590 & 5.634 & $941-1049$ & & & 7 \\
\hline$\gamma \mathrm{U}$ & $\mathrm{W}$ & $I m \overline{3} m$ & 3.490 & 3.490 & 3.490 & $1049-1408-$ & & $\begin{array}{c}2.5 \text { at } \% \mathrm{Al} \\
7.6 \text { at } \% \mathrm{Ga}\end{array}$ & $\begin{array}{c}9 \\
26\end{array}$ \\
\hline $\mathrm{Al}$ & $\mathrm{Cu}$ & $F m \overline{3} m$ & 4.041 & 4.041 & 4.041 & $<933$ & $<1$ at.\% Ga & & 7 \\
\hline $\mathrm{Ga}$ & $\mathrm{Ga}$ & $C m c m$ & 5.658 & 5.658 & 5.658 & $<303$ & & & 7 \\
\hline $\mathrm{UAl}_{2}$ & $\mathrm{MgCu}_{2}$ & $F d \overline{3} m$ & 7.776 & 7.776 & 7.776 & $<1893$ & & & 11 \\
\hline $\mathrm{UAl}_{3}$ & $\mathrm{Cu}_{3} \mathrm{Au}$ & $P m \overline{3} m$ & 4.266 & 4.266 & 4.266 & $<1623$ & & & 12 \\
\hline $\mathrm{UAl}_{4}$ & $\mathrm{UAl}_{4}$ & $I m m a$ & 4.401 & 6.255 & 13.727 & $<1004$ & & & 10 \\
\hline $\mathrm{U}_{3} \mathrm{Ga}_{5}$ & $\mathrm{Pu}_{3} \mathrm{Pd}_{5}$ & $\mathrm{Cmcm}$ & 9.396 & 7.575 & 9.387 & $<1533$ & & & 23 \\
\hline $\mathrm{UGa}_{2}$ & $\mathrm{AlB}_{2}$ & $P 6 / m m$ & 4.212 & 4.212 & 4.024 & $<1629$ & & & 15 \\
\hline $\mathrm{UGa}_{3}$ & $\mathrm{Cu}_{3} \mathrm{Au}$ & $P m \overline{3} m$ & 4.257 & 4.257 & 4.257 & $<1523$ & & & \\
\hline
\end{tabular}


Table 2

\begin{tabular}{|c|c|c|c|c|}
\hline \multicolumn{2}{|l|}{ samples } & \multirow{2}{*}{$\begin{array}{l}\text { SEM-EDS } \\
\text { analyses } \\
\text { Phase } \\
\text { analysis }\end{array}$} & \multicolumn{2}{|l|}{ DRX analyses } \\
\hline $\begin{array}{l}\text { Nominal } \\
\text { composition }\end{array}$ & $\begin{array}{l}\text { Metallurgic } \\
\text { al state }\end{array}$ & & $\begin{array}{l}\text { Phase } \\
\text { identification }\end{array}$ & Lattice parameters $(\AA)$ \\
\hline U57Ga43 & as-cast & $\begin{array}{l}\text { U92Ga8 } \\
\text { U38Ga62 }\end{array}$ & $\begin{array}{l}\alpha \mathrm{U} \\
\mathrm{U}_{3} \mathrm{Ga}_{5}\end{array}$ & $a=9.404(2) ; b=7.575(2) ; c=9.414(2)$ \\
\hline U54Ga46 & as-cast & $\begin{array}{l}\text { U91Ga9 } \\
\text { U38Ga62 }\end{array}$ & $\begin{array}{l}\alpha \mathrm{U} \\
\mathrm{U}_{3} \mathrm{Ga}_{5}\end{array}$ & $a=9.398(2) ; b=7.585(2) ; c=9.404(2)$ \\
\hline U40Ga60 & as-cast & $\begin{array}{l}\text { U91Ga9 } \\
\text { U38Ga62 }\end{array}$ & $\begin{array}{l}\alpha \mathrm{U} \\
\mathrm{U}_{3} \mathrm{Ga}_{5}\end{array}$ & $a=9.394(2) ; b=7.587(2) ; c=9.414(2)$ \\
\hline U39Ga61 & as-cast & $\begin{array}{l}\text { U92Ga8 } \\
\text { U38Ga62 } \\
\text { U34Ga66 }\end{array}$ & $\begin{array}{l}\alpha \mathrm{U} \\
\mathrm{U}_{3} \mathrm{Ga}_{5} \\
\mathrm{UGa} 2\end{array}$ & $\begin{array}{l}a=9.394(2) ; b=7.587(2) ; c=9.414(2) \\
a=4,210(1) ; c=4,012(1)\end{array}$ \\
\hline U39Ga61 & $1150 \mathrm{~K}$ & $\begin{array}{l}\text { U93Ga7 } \\
\text { U38Ga62 } \\
\text { U34Ga66 }\end{array}$ & $\begin{array}{l}\alpha \mathrm{U} \\
\mathrm{U}_{3} \mathrm{Ga}_{5} \\
\mathrm{UGa} 2\end{array}$ & $\begin{array}{l}a=9.394(2) ; b=7.587(2) ; c=9.414(2) \\
a=4,209(1) ; c=4,017(1)\end{array}$ \\
\hline U36Ga64 & $\mathrm{HF}$ & $\begin{array}{l}\text { U33Ga67 } \\
\text { U38Ga62 }\end{array}$ & $\begin{array}{l}\mathrm{UGa}_{2} \\
\mathrm{U}_{3} \mathrm{Ga}_{5}\end{array}$ & $\begin{array}{l}a=4,209(1) ; c=4,015(1) \\
a=9.398(2) ; b=7.585(2) ; c=9.401(2)\end{array}$ \\
\hline U30Ga70 & $\mathrm{HF}$ & $\begin{array}{l}\text { U25Ga75 } \\
\text { U34Ga66 }\end{array}$ & $\begin{array}{l}\mathrm{UGa}_{3} \\
\mathrm{UGa}_{2}\end{array}$ & $\begin{array}{l}a=4.256(1) \\
a=4,210(1) ; c=4,018(1)\end{array}$ \\
\hline $\mathrm{U} 25 \mathrm{Ga} 75$ & $1150 \mathrm{~K}$ & $\mathrm{U} 25 \mathrm{Ga} 75$ & $\mathrm{UGa}_{3}$ & $a=4.255(1)$ \\
\hline
\end{tabular}


Table 3 :.

\begin{tabular}{|l|l|l|}
\hline Sample nominal composition & Temperature $(\mathrm{K})$ & Transformation reaction \\
\hline \multirow{3}{*}{ U25Ga75 } & 1287 & $\mathrm{UGa}_{3} \rightarrow \mathrm{UGa}_{2}+\mathrm{L}$ \\
\cline { 2 - 3 } & 1335 & liquidus \\
\hline U38Ga62 & 1272 & $\mathrm{U}_{3} \mathrm{Ga}_{5} \rightarrow \mathrm{UGa}_{2}+\mathrm{L}$ \\
\cline { 2 - 3 } & 1355 & liquidus \\
\hline U40Ga60 & 1275 & $\mathrm{U}_{3} \mathrm{Ga}_{5} \rightarrow \mathrm{UGa}_{2}+\mathrm{L}$ \\
\cline { 2 - 3 } & 1348 & liquidus \\
\hline \multirow{5}{*}{ U5Ga46 } & 659 & $\alpha \mathrm{U} \rightarrow \beta \mathrm{U}$ \\
\cline { 2 - 3 } & 736 & $\beta \mathrm{U} \rightarrow \gamma \mathrm{U}$ \\
\cline { 2 - 3 } & 1020 & $\mathrm{U}_{3} \mathrm{Ga}_{5}+\gamma \mathrm{U} \rightarrow \mathrm{L}$ \\
\cline { 2 - 3 } & 1236 & $\mathrm{U}_{3} \mathrm{Ga}_{5} \rightarrow \mathrm{UGa} \mathrm{U}_{2}+\mathrm{L}$ \\
\cline { 2 - 3 } & 1350 & liquidus \\
\hline U70Ga30 & 659 & $\alpha \mathrm{U} \rightarrow \beta \mathrm{U}$ \\
\cline { 2 - 3 } & 735 & $\beta \mathrm{U} \rightarrow \gamma \mathrm{U}$ \\
\cline { 2 - 3 } & 1020 & $\mathrm{U}_{3} \mathrm{Ga}_{5}+\gamma \mathrm{U} \rightarrow \mathrm{L}$ \\
\cline { 2 - 3 } & 1138 & liquidus \\
\hline
\end{tabular}


Table 4:

\begin{tabular}{|l|l|}
\hline Sample composition; heat-treatment & $38 \mathrm{U}-62 \mathrm{Ga} ; 1373 \mathrm{~K}, 6 \mathrm{~h}$ \\
\hline Refined formula & $\mathrm{U}_{3} \mathrm{Ga}_{5}$ \\
\hline Crystal system; space group & orthorhombic; Cmcm $\left(\mathrm{n}^{\circ} 63\right)$ \\
\hline Lattice parameters ( $\AA$ ) & $\begin{array}{l}a=9,4420(6), \\
b=7,6291(5), \\
c=9,4486(7)\end{array}$ \\
\hline$\theta$ range $\left(^{\circ}\right)$ & $3.43-39.74$ \\
\hline Reflections collected / R int & $3426 / 0.0396$ \\
\hline $\begin{array}{l}\text { unique reflections / unique }\left[\mathrm{F}^{2}>2 \sigma\left(\mathrm{F}^{2}\right)\right] / \\
\text { parameters }\end{array}$ & $1124 / 1062 / 27$ \\
\hline Reliability factors* $\left[\mathrm{F}^{2}>2 \sigma\left(\mathrm{F}^{2}\right)\right]$ & $\mathrm{R}_{1}=0.0238 ; w \mathrm{R}_{2}=0.0568$ \\
\hline Residual Peaks $\left(\overline{\mathrm{e}} \AA^{-3}\right)$ & $6.375 /-4.810$ \\
\hline
\end{tabular}

$\mathrm{R}_{1}=\sum \| \mathrm{F}_{0}|-| \mathrm{FC}_{\mathrm{C}}|/| \mathrm{FC}_{\mathrm{C}} \mid$

(for

$\left.\mathrm{F}^{2}>2 \sigma\left(\mathrm{F}^{2}\right)\right)$

$w \mathrm{R}_{2}=\left[\sum w\left(\mathrm{~F}_{\mathrm{o}}^{2}-\mathrm{F}_{\mathrm{c}}^{2}\right)^{2} / w \mathrm{~F}_{\mathrm{o}}^{4}\right.$

$1 / 2$, where

$w^{-1}=\left[\sigma^{2}(\right.$

$\left.\mathrm{F}_{\mathrm{o}}^{2}\right)+$

$(A p)^{2}+$

$\mathrm{Bp}], \mathrm{p}=$

$\left[\max \left(\mathrm{F}_{\mathrm{o}}^{2}\right.\right.$

,0) $+2 F_{c}^{2}$

]$/ 3$

Table 5:

\begin{tabular}{|c|c|c|c|c|c|}
\hline Atom & Wyckoff site & $\mathrm{x}$ & $\mathrm{y}$ & $\mathrm{z}$ & Ueq. $\left(\AA^{2}\right)$ \\
\hline $\mathrm{U}(1)$ & $8 e$ & $0.20701(2)$ & 0 & 0 & $0.00604(7)$ \\
\hline $\mathrm{U}(2)$ & $4 c$ & 0 & $0.63692(3)$ & $1 / 4$ & $0.00645(7)$ \\
\hline $\mathrm{Ga}(1)$ & $8 g$ & $0.20442(6)$ & $0.28288(9)$ & $1 / 4$ & $0.0079(2)$ \\
\hline $\mathrm{Ga}(2)$ & $8 f$ & 0 & $0.30530(8)$ & $0.05601(6)$ & $0.0079(2)$ \\
\hline $\mathrm{Ga}(3)$ & $4 c$ & 0 & $0.0241(2)$ & $1 / 4$ & $0.0078(2)$ \\
\hline
\end{tabular}


Table 6 :

\begin{tabular}{|c|c|}
\hline $\begin{array}{l}\text { Phase denomination } \\
\text { Model }\end{array}$ & Gibbs energy parameters $\left(\mathrm{J} \mathrm{mol}^{-1}\right)$ \\
\hline $\begin{array}{l}\text { Liquid } \\
(\mathrm{U}, \mathrm{Ga})_{1}\end{array}$ & 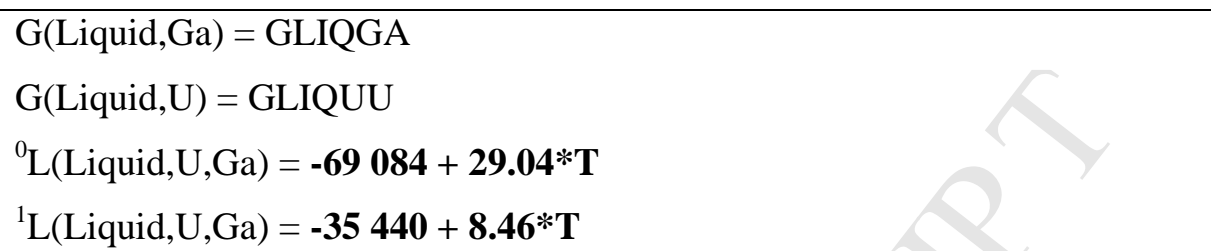 \\
\hline $\begin{array}{l}\text { Ga (Ortho_Ga) } \\
(\mathrm{Ga})_{1}\end{array}$ & G(Ortho_Ga,Ga) = GHSERGA \\
\hline $\begin{array}{l}\mathrm{UGa}_{3} \\
(\mathrm{Ga})_{0.75}(\mathrm{U})_{0.25}\end{array}$ & $\mathrm{G}\left(\mathrm{Al}_{3} \mathrm{U}, \mathrm{Ga}: \mathrm{U}\right)=\mathbf{- 3 7} \mathbf{7 8 0}+\mathbf{3 . 2 7} * \mathbf{T}+0.75 * \mathrm{GHSERGA}+0.25 * \mathrm{GHSERUU}$ \\
\hline $\begin{array}{l}\mathrm{UGa}_{2} \\
(\mathrm{Ga})_{0.667}(\mathrm{U})_{0.333}\end{array}$ & $\mathrm{G}\left(\mathrm{Ga}_{2} \mathrm{U}, \mathrm{Ga}: \mathrm{U}\right)=\mathbf{- 4 1} \mathbf{1 2 9}+\mathbf{4 . 6 0} * \mathbf{T}+0.667 * \mathrm{GHSERGA}+0.333 * \mathrm{GHSERUU}$ \\
\hline $\begin{array}{l}\mathrm{U}_{3} \mathrm{Ga}_{5} \\
(\mathrm{Ga})_{0.625}(\mathrm{U})_{0.375}\end{array}$ & $\mathrm{G}\left(\mathrm{Ga}_{5} \mathrm{U}_{3}, \mathrm{Ga}: \mathrm{U}\right)=\mathbf{- 3 8 7 9 9}+\mathbf{4 . 0 2} * \mathbf{T}+0.625 * \mathrm{GHSERGA}+0.375 * \mathrm{GHSERUU}$ \\
\hline $\begin{array}{l}\gamma \mathrm{U}\left(\mathrm{Bcc} \_\mathrm{A} 2\right) \\
(\mathrm{Ga}, \mathrm{U})_{1}(\mathrm{VA})_{3}\end{array}$ & $\begin{array}{l}\text { G(Bcc_A2,Ga:VA })=\text { GBCCGA } \\
\mathrm{G}\left(\mathrm{Bcc} \_A 2, \mathrm{U}: \mathrm{VA}\right)=\mathrm{GBCCUU} \\
{ }^{0} \mathrm{~L}\left(\mathrm{Bcc} \_\mathrm{A} 2, \mathrm{U}, \mathrm{Ga}: \mathrm{VA}\right)=\mathbf{- 3 6 8 8 0}+\mathbf{1 1 . 2 8} * \mathbf{T} \\
{ }^{1} \mathrm{~L}\left(\mathrm{Bcc} \_\mathrm{A} 2, \mathrm{U}, \mathrm{Ga}\right)=\mathbf{- 6} \mathbf{6 1 7}\end{array}$ \\
\hline $\begin{array}{l}\beta \mathrm{U}(\text { Tetra_U) } \\
(\mathrm{U}, \mathrm{Ga})_{1}\end{array}$ & $\begin{array}{l}\text { G(Tetra_U,Ga) = GHSERGA + } 3 \mathbf{6 6 0} \\
\text { G(Tetra_U,U })=\text { GTETRAUU } \\
{ }^{0} \text { L }(\text { Tetra_U,U,Ga })=\mathbf{- 2 1} \mathbf{7 4 5}\end{array}$ \\
\hline $\begin{array}{l}\alpha \mathrm{U} \text { (Ortho_A20) } \\
(\mathrm{U})_{1}\end{array}$ & G(Ortho_A20,U) = GHSERUU \\
\hline
\end{tabular}


Table 7 :

\begin{tabular}{|c|c|c|c|c|}
\hline Sample & Phase field (XRD) & \multicolumn{3}{|c|}{ Phase composition (SEM-EDS) } \\
\hline $30 \mathrm{U}-59 \mathrm{Al}-11 \mathrm{Ga}$ & $\mathrm{UX}_{3}+\mathrm{UAl}_{2}$ & $\mathrm{UX}_{3}: \mathrm{U}_{25} \mathrm{Al}_{59} \mathrm{Ga}_{16}$ & $\mathrm{UAl}_{2}: \mathrm{U}_{34} \mathrm{Al}_{61} \mathrm{Ga}_{5}$ & \\
\hline 28U-66Al-6Ga & $\mathrm{UX}_{3}+\mathrm{UAl}_{2}$ & $\mathrm{UX}_{3}: \mathrm{U}_{25} \mathrm{Al}_{68} \mathrm{Ga}_{7}$ & $\mathrm{UAl}_{2}: \mathrm{U}_{34} \mathrm{Al}_{63} \mathrm{Ga}_{3}$ & \\
\hline $18 \mathrm{U}-47 \mathrm{Al}-35 \mathrm{Ga}$ & $\mathrm{UX}_{3}+\mathrm{Al}$ & $\mathrm{UX}_{3}: \mathrm{U}_{25} \mathrm{Al}_{56} \mathrm{Ga}_{39}$ & $\mathrm{Al}: \mathrm{Al}_{88} \mathrm{Ga}_{12}$ & \\
\hline $52 \mathrm{U}-31 \mathrm{Al}-17 \mathrm{Ga}$ & $\mathrm{UAl}_{2}+\mathrm{U}$ & $\mathrm{UAl}_{2}: \mathrm{U}_{34} \mathrm{Al}_{43} \mathrm{Ga}_{23}$ & $\mathrm{U}: \mathrm{U}_{98} \mathrm{Ga}_{2}$ & \\
\hline $52 \mathrm{U}-42 \mathrm{Al}-6 \mathrm{Ga}$ & $\mathrm{UAl}_{2}+\mathrm{U}$ & $\mathrm{UAl}_{2}: \mathrm{U}_{34} \mathrm{Al}_{57} \mathrm{Ga}_{9}$ & $\mathrm{U}: \mathrm{U}_{99} \mathrm{Al}_{1}$ & \\
\hline $33 \mathrm{U}-31 \mathrm{Al}-36 \mathrm{Ga}$ & $\mathrm{UAl}_{2}+\mathrm{UX}_{3}$ & $\mathrm{UAl}_{2}: \mathrm{U}_{34} \mathrm{Al}_{34} \mathrm{Ga}_{33}$ & $\mathrm{UX}_{3}: \mathrm{U}_{26} \mathrm{Al}_{19} \mathrm{Ga}_{55}$ & \\
\hline $13 \mathrm{U}-71 \mathrm{Al}-16 \mathrm{Ga}$ & $\mathrm{UX}_{3}+\mathrm{Al}$ & $\mathrm{UX}_{3}: \mathrm{U}_{25} \mathrm{Al}_{52} \mathrm{Ga}_{23}$ & $\mathrm{Al}: \mathrm{Al}_{95} \mathrm{Ga}_{5}$ & \\
\hline 49U-9Al-42Ga & $\mathrm{U}_{3} \mathrm{Ga}_{5}+\mathrm{UAl}_{2}+\mathrm{U}$ & $\mathrm{U}_{3} \mathrm{Ga}_{5}: \mathrm{U}_{38} \mathrm{Al}_{8} \mathrm{Ga}_{54}$ & $\mathrm{UAl}_{2}: \mathrm{U}_{34} \mathrm{Al}_{33} \mathrm{Ga}_{33}$ & $\mathrm{U}: \mathrm{U}_{97} \mathrm{Al}_{3}$ \\
\hline $30 \mathrm{U}-13 \mathrm{Al}-57 \mathrm{Ga}$ & $\mathrm{UX}_{3}+\mathrm{UAl}_{2}+\mathrm{UGa}_{2}$ & $\mathrm{UX}_{3}: \mathrm{U}_{25} \mathrm{Al}_{19} \mathrm{Ga}_{57}$ & $\mathrm{UAl}_{2}: \mathrm{U}_{33} \mathrm{Al}_{32} \mathrm{Ga}_{34}$ & $\mathrm{UGa}_{2}: \mathrm{U}_{33} \mathrm{Al}_{8} \mathrm{Ga}_{59}$ \\
\hline $32 \mathrm{U}-6 \mathrm{Al}-63 \mathrm{Ga}$ & $\mathrm{UX}_{3}+\mathrm{UGa}_{2}$ & $\mathrm{UX}_{3}: \mathrm{U}_{25} \mathrm{Al}_{10} \mathrm{Ga}_{65}$ & $\mathrm{UGa}_{2}: \mathrm{U}_{33} \mathrm{Al}_{5} \mathrm{Ga}_{62}$ & \\
\hline $44 \mathrm{U}-13 \mathrm{Al}-57 \mathrm{Ga}$ & $\mathrm{U}_{3} \mathrm{Ga}_{5}+\mathrm{UAl}_{2}$ & $\mathrm{U}_{3} \mathrm{Ga}_{5}: \mathrm{U}_{37} \mathrm{Al}_{9} \mathrm{Ga}_{53}$ & $\mathrm{UAl}_{2}: \mathrm{U}_{33} \mathrm{Al}_{35} \mathrm{Ga}_{32}$ & \\
\hline 37U-7Al-56Ga & $\mathrm{U}_{3} \mathrm{Ga}_{5}+\mathrm{UGa}_{2}$ & $\mathrm{U}_{3} \mathrm{Ga}_{5}: \mathrm{U}_{38} \mathrm{Al}_{7} \mathrm{Ga}_{54}$ & $\mathrm{UGa}_{2}: \mathrm{U}_{33} \mathrm{Al}_{8} \mathrm{Ga}_{59}$ & \\
\hline 20U-66Al-14Ga & $\mathrm{UAl}_{4}+\mathrm{UX}_{3}+\mathrm{Al}$ & $\mathrm{UAl}_{4}: \mathrm{U}_{20} \mathrm{Al}_{65} \mathrm{Ga}_{15}$ & $\mathrm{UAl}_{3}: \mathrm{U}_{25} \mathrm{Al}_{56} \mathrm{Ga}_{19}$ & $\mathrm{Al}: \mathrm{Al}_{98} \mathrm{Ga}_{2}$ \\
\hline $23 \mathrm{U}-65 \mathrm{Al}-12 \mathrm{Ga}$ & $\mathrm{UAl}_{4}+\mathrm{UX}_{3}$ & $\mathrm{UAl}_{4}: \mathrm{U}_{20} \mathrm{Al}_{69} \mathrm{Ga}_{11}$ & $\mathrm{UAl}_{3}: \mathrm{U}_{25} \mathrm{Al}_{62} \mathrm{Ga}_{13}$ & \\
\hline $16 \mathrm{U}-72 \mathrm{Al}-12 \mathrm{Ga}$ & $\mathrm{UAl}_{4}+\mathrm{Al}$ & $\mathrm{UAl}_{4}: \mathrm{U}_{20} \mathrm{Al}_{68} \mathrm{Ga}_{12}$ & $\mathrm{Al}: \mathrm{Al}_{96} \mathrm{Ga}_{5}$ & \\
\hline $16 \mathrm{U}-80 \mathrm{Al}-4 \mathrm{Ga}$ & $\mathrm{UAl} 4+\mathrm{Al}$ & $\mathrm{UAl}_{4}: \mathrm{U}_{20} \mathrm{Al}_{75} \mathrm{Ga}_{5}$ & $\mathrm{Al}: \mathrm{Al}_{100}$ & \\
\hline $16 \mathrm{U}-74 \mathrm{Al}-10 \mathrm{Ga}$ & $\mathrm{UAl}_{4}+\mathrm{Al}$ & $\mathrm{UAl}_{4}: \mathrm{U}_{20} \mathrm{Al}_{68} \mathrm{Ga}_{12}$ & $\mathrm{Al}: \mathrm{Al}_{98} \mathrm{Ga}_{2}$ & \\
\hline $18 \mathrm{U}-66 \mathrm{Al}-12 \mathrm{Ga}$ & $\mathrm{UAl}_{4}+\mathrm{Al}$ & $\mathrm{UAl}_{4}: \mathrm{U}_{20} \mathrm{Al}_{65} \mathrm{Ga}_{15}$ & $\mathrm{Al}: \mathrm{Al}_{100}$ & \\
\hline
\end{tabular}


Table 8 : .

\begin{tabular}{|c|c|c|c|c|}
\hline Sample & Phase field (XRD) & \multicolumn{3}{|c|}{ Phase composition (SEM-EDS) } \\
\hline $34 \mathrm{U}-11 \mathrm{Al}-56 \mathrm{Ga}$ & $\mathrm{UX}_{3}+\mathrm{UGa}_{2}$ & $\mathrm{UX}_{3}: \mathrm{U}_{25} \mathrm{Al}_{18} \mathrm{Ga}_{57}$ & $\mathrm{UGa}_{2}: \mathrm{U}_{34} \mathrm{Al}_{9} \mathrm{Ga}_{57}$ & \\
\hline $38 \mathrm{U}-4 \mathrm{Al}-58 \mathrm{Ga}$ & $\mathrm{U}_{3} \mathrm{Ga}_{5}+\mathrm{UGa}_{2}$ & $\mathrm{U}_{3} \mathrm{Ga}_{5}: \mathrm{U}_{38} \mathrm{Al}_{5} \mathrm{Ga}_{57}$ & $\mathrm{UGa}_{2}: \mathrm{U}_{34}, \mathrm{Al}_{6} \mathrm{Ga}_{60}$ & \\
\hline $43 \mathrm{U}-12 \mathrm{Al}-45 \mathrm{Ga}$ & $\mathrm{U}_{3} \mathrm{Ga}_{5}+\mathrm{UAl}_{2}+\mathrm{U}$ & $\mathrm{U}_{3} \mathrm{Ga}_{5}: \mathrm{U}_{38} \mathrm{Al}_{7} \mathrm{Ga}_{55}$ & $\mathrm{UAl}_{2}: \mathrm{U}_{34} \mathrm{Al}_{30} \mathrm{Ga}_{36}$ & $\mathrm{U}: \mathrm{U}_{96} \mathrm{Ga}_{4}$ \\
\hline $35 \mathrm{U}-17 \mathrm{Al}-48 \mathrm{Ga}$ & $\mathrm{UX}_{3}+\mathrm{UAl}_{2}+\mathrm{UGa}_{2}$ & $\mathrm{UX}_{3}: \mathrm{U}_{26} \mathrm{Al}_{17} \mathrm{Ga}_{57}$ & $\mathrm{UAl}_{2}: \mathrm{U}_{34} \mathrm{Al}_{28} \mathrm{Ga}_{38}$ & $\mathrm{UGa}_{2}: \mathrm{U}_{34} \mathrm{Al}_{8} \mathrm{Ga}_{58}$ \\
\hline $52 \mathrm{U}-31 \mathrm{Al}-17 \mathrm{Ga}$ & $\mathrm{UAl}_{2}+\mathrm{U}$ & $\mathrm{UAl}_{2}: \mathrm{U}_{34} \mathrm{Al}_{43} \mathrm{Ga}_{23}$ & $\mathrm{U}: \mathrm{U}_{97} \mathrm{Ga}_{3}$ & \\
\hline 35U-58Al-7Ga & $\mathrm{UAl}_{2}+\mathrm{U}$ & $\mathrm{UAl}_{2}: \mathrm{U}_{33} \mathrm{Al}_{59} \mathrm{Ga}_{8}$ & $\mathrm{U}: \mathrm{U}_{95} \mathrm{Al}_{3} \mathrm{Ga}_{2}$ & \\
\hline $31 \mathrm{U}-58 \mathrm{Al}-11 \mathrm{Ga}$ & $\mathrm{UAl}_{2}+\mathrm{UX}_{3}$ & $\mathrm{UAl}_{2}: \mathrm{U}_{33} \mathrm{Al}_{61} \mathrm{Ga}_{6}$ & $\mathrm{UX}_{3}: \mathrm{U}_{25} \mathrm{Al}_{57} \mathrm{Ga}_{18}$ & \\
\hline 40U-5Al-55Ga & $\mathrm{U}_{3} \mathrm{Ga}_{5}+\mathrm{U}$ & $\mathrm{U}_{3} \mathrm{Ga}_{5}: \mathrm{U}_{38} \mathrm{Al}_{5} \mathrm{Ga}_{57}$ & $\mathrm{U}: \mathrm{U}_{94} \mathrm{Ga}_{6}$ & \\
\hline 37U-9Al-55Ga & $\mathrm{U}_{3} \mathrm{Ga}_{5}+\mathrm{UGa}_{2}$ & $\mathrm{U}_{3} \mathrm{Ga}_{5}: \mathrm{U}_{38} \mathrm{Al}_{8} \mathrm{Ga}_{54}$ & $\mathrm{UGa}_{2}: \mathrm{U}_{34} \mathrm{Al}_{10} \mathrm{Ga}_{56}$ & \\
\hline $38 \mathrm{U}-20 \mathrm{Al}-42 \mathrm{Ga}$ & $\mathrm{U}_{3} \mathrm{Ga}_{5}+\mathrm{UAl}_{2}$ & $\mathrm{U}_{3} \mathrm{Ga}_{5}: \mathrm{U}_{39} \mathrm{Al}_{6} \mathrm{Ga}_{55}$ & $\mathrm{UAl}_{2}: \mathrm{U}_{34} \mathrm{Al}_{30} \mathrm{Ga}_{36}$ & \\
\hline $31 \mathrm{U}-26 \mathrm{Al}-43 \mathrm{Ga}$ & $\mathrm{UAl}_{2}+\mathrm{UX}_{3}$ & $\mathrm{UAl}_{2}: \mathrm{U}_{33} \mathrm{Al}_{31} \mathrm{Ga}_{36}$ & $\mathrm{UX}_{3}: \mathrm{U}_{25} \mathrm{Al}_{19} \mathrm{Ga}_{56}$ & \\
\hline
\end{tabular}

Table 9 :

\begin{tabular}{|c|c|}
\hline $\begin{array}{l}\text { Phase } \\
\text { denomination } \\
\text { Model }\end{array}$ & Gibbs energy parameters $\left(\mathrm{J} \mathrm{mol}^{-1}\right)$ \\
\hline $\begin{array}{l}\text { Liquid } \\
(\mathrm{U}, \mathrm{Al}, \mathrm{Ga})_{1}\end{array}$ & ${ }^{0} \mathrm{~L}(\mathrm{Liquid}, \mathrm{U}, \mathrm{Al}, \mathrm{Ga})=\mathbf{- 1 5 5} 000$ \\
\hline $\begin{array}{l}\mathrm{U}_{3} \mathrm{Ga}_{5} \\
(\mathrm{Al}, \mathrm{Ga})_{0.625}(\mathrm{U})_{0.375}\end{array}$ & $\begin{array}{l}\mathrm{G}\left(\mathrm{U}_{3} \mathrm{Ga}_{5}, \mathrm{Al}: \mathrm{U}\right)=\mathbf{- 2 0 0 0 0}+\mathbf{4} * \mathrm{~T}+0.667 * \mathrm{GHSERGA}+0.333 * \mathrm{GHSERUU} \\
{ }^{0} \mathrm{~L}(\mathrm{Al}, \mathrm{Ga}: \mathrm{U})=\mathbf{- 1 5} \mathbf{0 0 0}\end{array}$ \\
\hline $\begin{array}{l}\mathrm{UGa}_{2} \\
(\mathrm{Al}, \mathrm{Ga})_{0.667}(\mathrm{U})_{0.333}\end{array}$ & $\begin{array}{l}\mathrm{G}\left(\mathrm{UGa}_{2}, \mathrm{Al}: \mathrm{U}\right)=\mathbf{- 2 5} 000+\mathbf{5} * \mathbf{T}+0.667 * \mathrm{GHSERGA}+0.333 * \mathrm{GHSERUU} \\
{ }^{0} \mathrm{~L}(\mathrm{U}: \mathrm{Al}, \mathrm{Ga})=-13000\end{array}$ \\
\hline $\begin{array}{l}\mathrm{UX}_{3} \\
(\mathrm{Al}, \mathrm{Ga})_{0.75}(\mathrm{U})_{0.25}\end{array}$ & $\begin{array}{l}{ }^{0} \mathrm{~L}(\mathrm{Al}, \mathrm{Ga}: \mathrm{U})=\mathbf{- 2 3 0 0 0} \\
{ }^{1} \mathrm{~L}(\mathrm{Al}, \mathrm{Ga}: \mathrm{U})=\mathbf{+ 5 0 0 0}\end{array}$ \\
\hline $\begin{array}{l}\mathrm{UAl}_{2} \\
(\mathrm{Al}, \mathrm{Ga})_{0.667}(\mathrm{U})_{0.333}\end{array}$ & $\begin{array}{l}\mathrm{G}\left(\mathrm{UAl}_{2}, \mathrm{Ga}: \mathrm{U}\right)=\mathbf{- 2 9} \mathbf{5 0 0}+\mathbf{2} * \mathbf{T}+0.667 * \mathrm{GHSERGA}+0.333^{*} \mathrm{GHSERUU} \\
{ }^{0} \mathrm{~L}\left(\mathrm{UAL}_{2}, \mathrm{Al}, \mathrm{Ga}: \mathrm{U}\right)=\mathbf{- 2 8} \mathbf{5 0 0}\end{array}$ \\
\hline $\begin{array}{l}\mathrm{UAl}_{4} \\
(\mathrm{Al}, \mathrm{Ga})_{0.8}(\mathrm{U})_{0.2}\end{array}$ & $\begin{array}{l}\mathrm{G}\left(\mathrm{UAl}_{4}, \mathrm{Ga}: \mathrm{U}\right)=\mathbf{- 2 9} \mathbf{0 0 0}+\mathbf{3} * \mathbf{T}+0.8 * \mathrm{GHSERGA}+0.2 * \mathrm{GHSERUU} \\
{ }^{0} \mathrm{~L}\left(\mathrm{UAl}_{4}, \mathrm{Al}, \mathrm{Ga}: \mathrm{U}\right)=\mathbf{- 2 1} \mathbf{0 0 0}\end{array}$ \\
\hline
\end{tabular}


Table 10..

\begin{tabular}{|l|l|l|l|l|}
\hline Reaction (on cooling) & \multirow{2}{*}{$\mathrm{T}(\mathrm{K})$} & \multicolumn{3}{|l|}{ Composition of the liquid } \\
\cline { 3 - 5 } & & at \% U & at.\% $\mathrm{Al}$ & at \% Ga \\
\hline Liquid $+\mathrm{UAl}_{3} \rightarrow \mathrm{UGa}_{2}+\mathrm{UAl}_{2}$ & 1515.4 & 46.63 & 11.22 & 42.15 \\
\hline Liquid $+\mathrm{UGa}_{2} \rightarrow \mathrm{U}_{3} \mathrm{Ga}_{5}+\mathrm{UAl}_{2}$ & 1444.6 & 53.56 & 9.66 & 36.78 \\
\hline Liquid $\rightarrow \mathrm{UAl}_{2}+\mathrm{U}_{3} \mathrm{Ga}_{5}+\gamma \mathrm{U}$ & 1262.5 & 72.70 & 4.95 & 22.35 \\
\hline Liquid $+\mathrm{UAl}_{4} \rightarrow \mathrm{UAl}_{3}+\mathrm{Al}$ & 898.9 & 1.07 & 94.22 & 4.71 \\
\hline
\end{tabular}




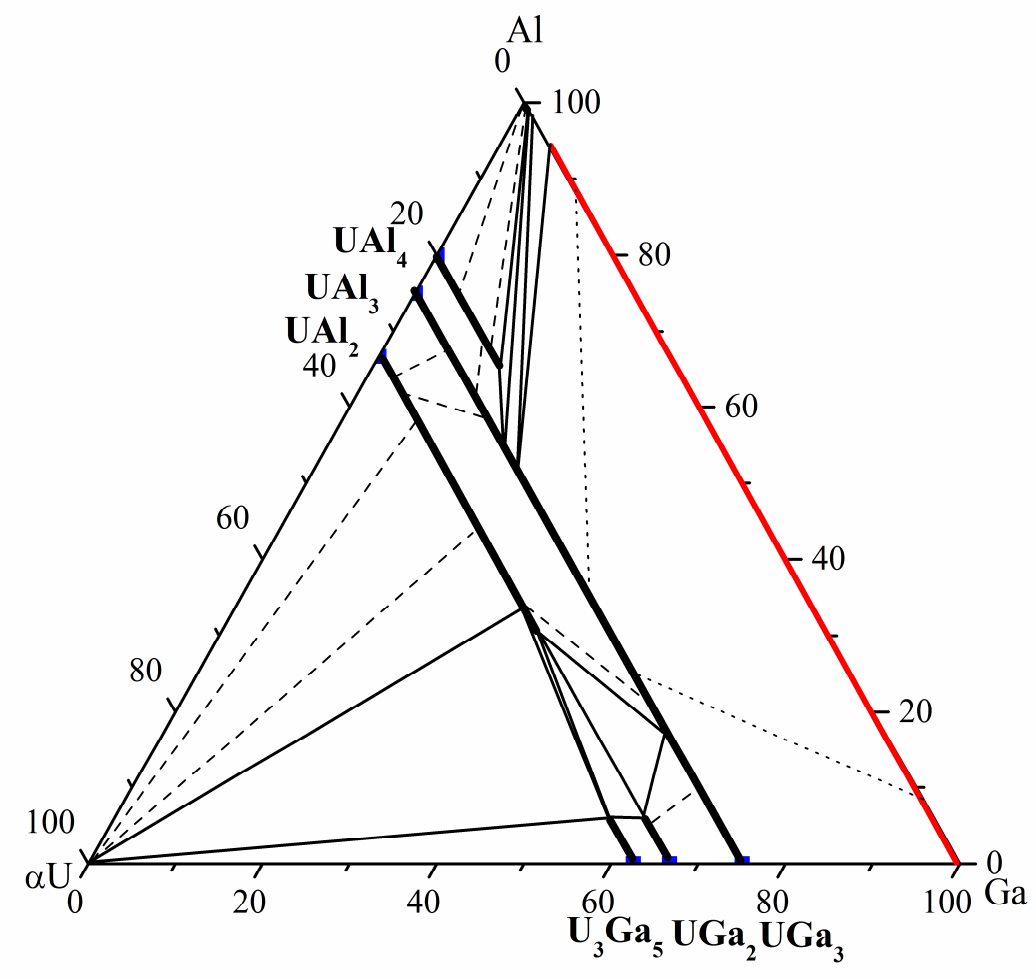




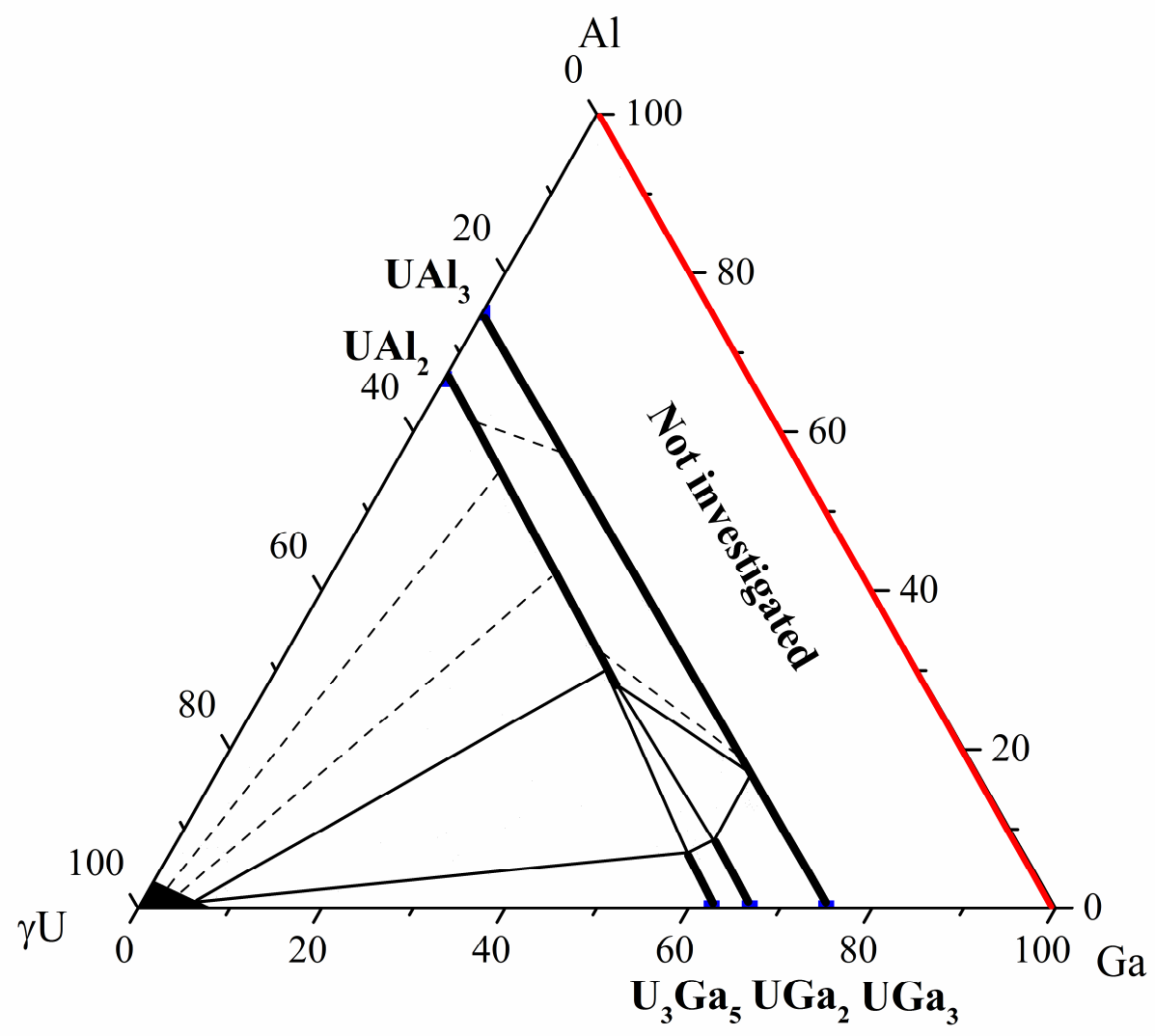




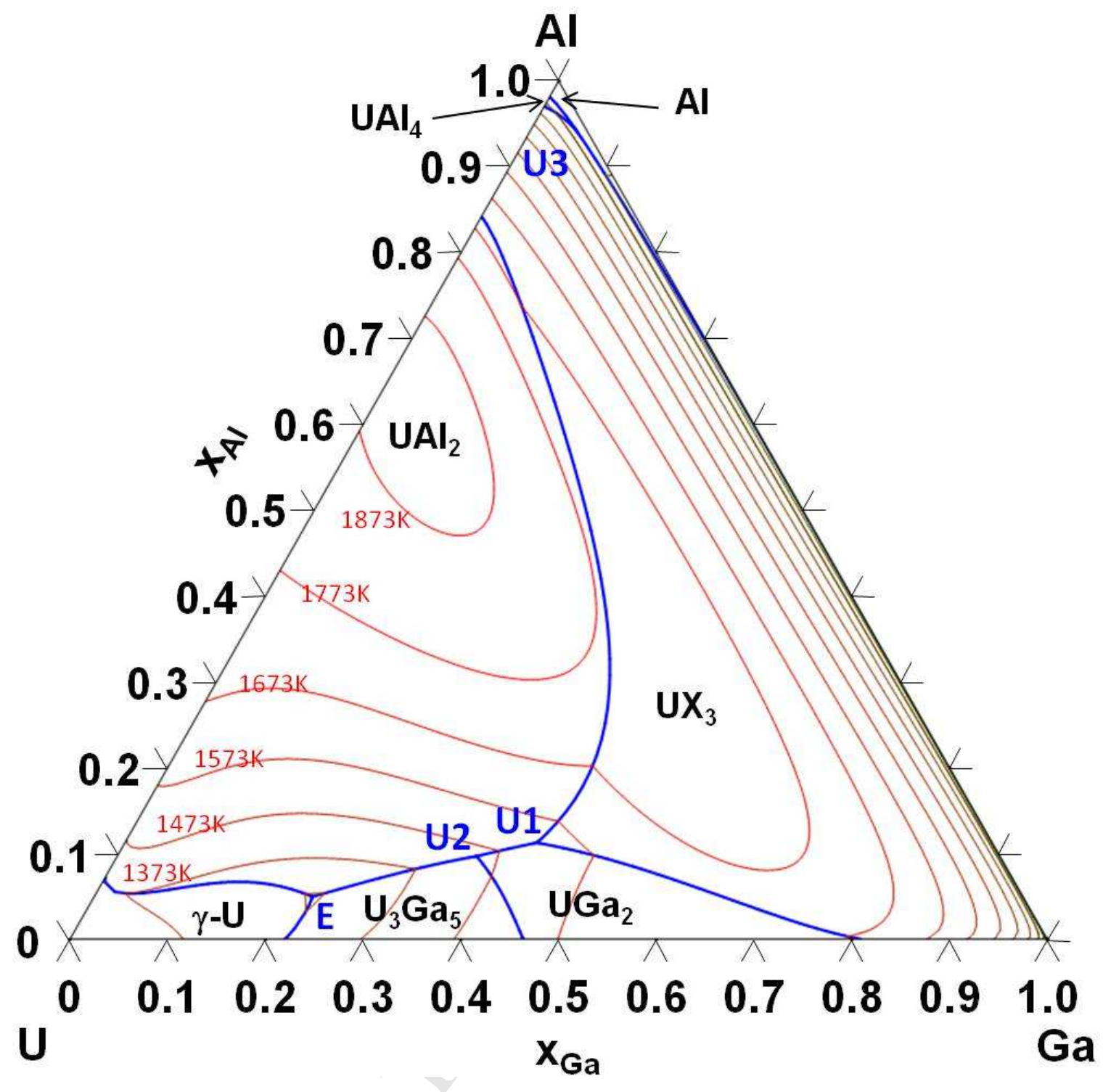




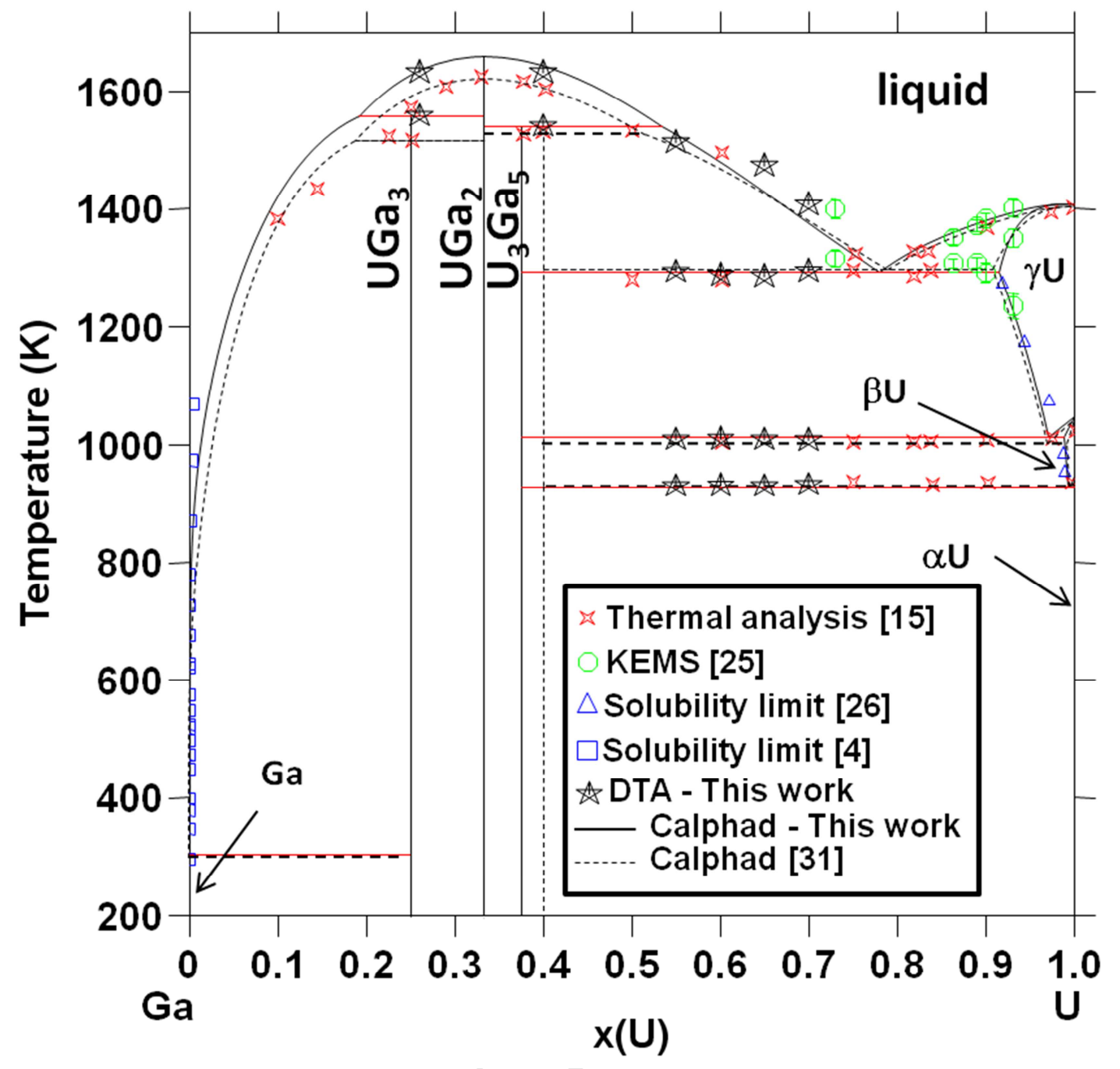




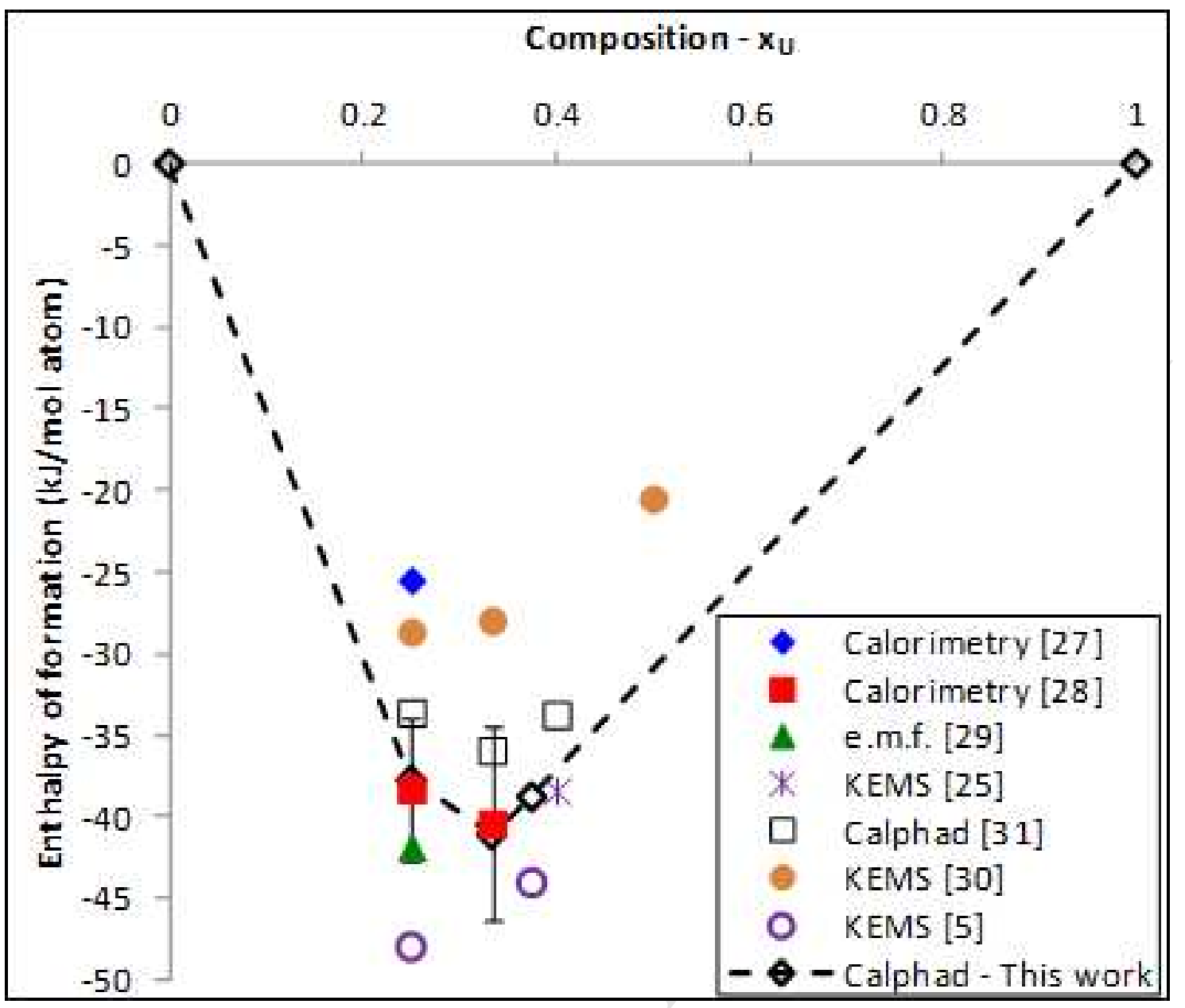



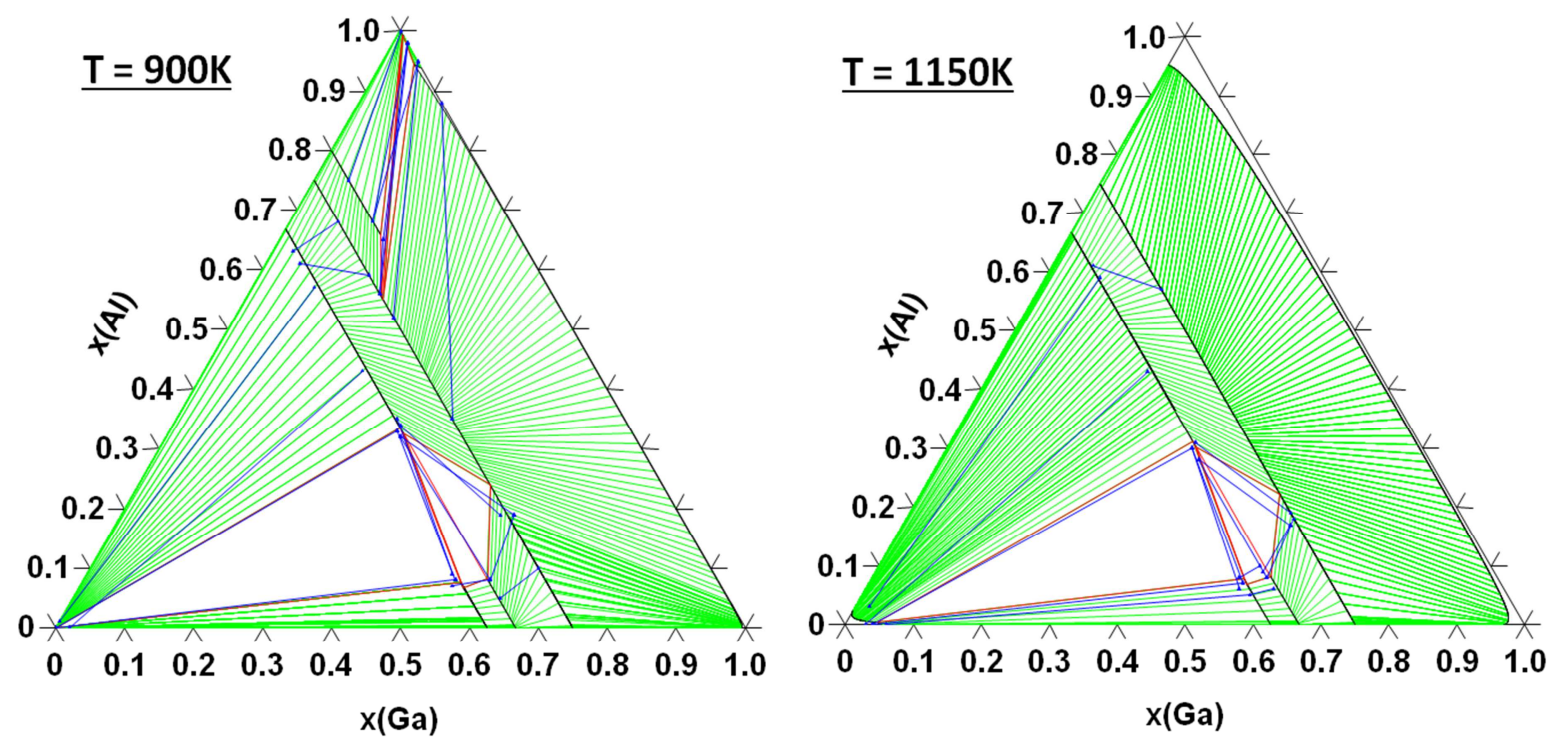


\section{HIGHLIGHTS :}

- The U-Ga phase-diagram was reassessed using classical and optimization methods.

- The U-Al-Ga system was experimentally investigated for two isothermal sections at 900 $\mathrm{K}$ and $1150 \mathrm{~K}$.

- The crystallographic properties of the equilibrium phases were checked.

- Thermodynamic assessment for the U-Al-Ga system has been constructed by the CALPHAD approach. 